\title{
PATERNALISM AND DEMOCRACY IN THE POLITICS OF ROBERT OWEN*
}

Popular conceptions of the politics of Robert Owen have changed surprisingly little since the early nineteenth century. Within a short time of the advent of his national campaign for Poor Law reform, Owen came under attack from radical parliamentary reformers on the grounds of his ostensible political conservatism. Among the rumours then afloat among the reformers, Richard Carlile later wrote, one was "that Mr. Owen was an instrument of the Government, to bring forward this plan of providing for the lower and poorer classes, for the purpose of drawing their attention from Parliamentary Reform". ${ }^{1}$ W. T. Sherwin, writing in April 1817, was more direct in advising his readers. Owen's scheme of "new fashioned poor houses" was "calculated to deprive you of your political rights, in every sense of the word". His educational plans would merely produce more loyal subjects of the Empire, "debarred from the enjoyment of the Rights of Man".' In his Black Dwarf, T. J. Wooler accused Owen of wanting to set up "pauper barracks", whose inhabitants "shall be reduced to mere automata, and all their feelings, passions and opinions are to be subjected to certain rules, which Mr. Owen, the tutelary deity of these novel elysiums, will lay down". William Cobbett's abrasive comments on the "parallelograms of paupers" are too well-known to bear repetition. ${ }^{3}$

These views of Owen's political intentions might have been of only antiquarian interest, had they not also come to dominate scholarly opinion

* I would like to thank the Editors of this journal for their comments on an earlier draft of this article, and the Managers of the Research Centre, King's College, Cambridge, for their assistance in funding my research.

1 Republican, 14 January 1820, p. 10.

2 Sherwin's Political Register, 26 April 1817, pp. 59-62.

3 Cobbett's Weekly Political Register, 2 August 1817, p. 569. The most full account of the radicals' reaction to Owen is in the Reformists' Register, 28 August 1817, pp. 129-60, in an article entitled "Let Us Alone, Mr. Owen". See also A. Cullen, Adventures in Socialism (Glasgow, 1910), p. 101, and J. Gans, "Robert Owen et la Classe Ouvrière", in: Le Mouvement Social, No 80 (1972), pp. 77-80. 
of Owen's politics, whence they have often passed to other students of the period. From the comment of William Lucas Sargant, Owen's first biographer, that "Owen's notions of government generally were anything but democratic, and had rather a paternal leaning", to more recent descriptions of Owen as "essentially a conservative", "anti-democratic", or simply "despotic", there has been a pronounced tendency to see Owen as a "paternal" (i.e. conservative) critic of "democracy" (whose meaning has more often been presumed than defined). ${ }^{4}$ Frank Podmore described Owen as "aristocratic in his methods and the whole cast of his mind", because "he appears always to have conceived of reform as something imposed [...] from above". Max Beer termed Owen "no democrat". R. H. Harvey noted that Owen's ideas on government "did not run along democratic channels", while Ralph Miliband has characterised Owen as a "Social Revolutionary" to whom forms of government were immaterial. Elsewhere it has been argued that Owen deplored "democracy", which he identified with militancy, that he had little sympathy for political reform, and held aloof from all popular democratic movements, that it was his American experience which confirmed Owen's rejection of political agitation, although the roots of "his political conservatism" were evident as early as the 1790's, that Owen was "completely indifferent" to both the 1832 and Chartist reform agitation, and finally, in a somewhat more imaginative vein, that Owen "simply had a vacant place in his mind where most men have political responses". 5

This type of verdict has not been entirely unanimous, however. Lloyd Jones, the only one among Owen's major biographers to have known him intimately, said the latter was friendly to reform in the House of Commons, despite his dislike of temporary expedients. More recently, the most

4 W. L. Sargant, Robert Owen and His Social Philosophy (London, 1860), pp. 37-38: E. Royle, Victorian Infidels and the Origins of the British Secularist Movement (Manchester, 1974), pp. 2, 44; R. A. Soloway, Prelates and People: Ecclesiastical Social Thought in England, 1783-1852 (London, 1969), p. 224; I. Prothero, Artisans and Politics in Early Nineteenth Century London (London, 1979), p. 254.

5 F. Podmore, Robert Owen (London, 1906), p. 427; M. Beer, A History of British Socialism (2 vols; London, 1929), I, p. 162; R. H. Harvey, Robert Owen, Social Idealist (Berkeley, 1949), p. 87; R. Miiioand, "The Politics of Robert Owen", in: Journal of the History of Ideas, XV (1954), pp. 233-35; R. G. Garnett, Co-operation and the Owenite Socialist Communities in Britain, 1825-45 (Manchester, 1972), p. 29; C. Tsuzuki, "Robert Owen and Revolutionary Politics", in: Robert Owen: Prophet of the Poor, ed. by S. Pollard and J. Salt (London, 1971), p. 13; J. Butt, "Robert Owen of New Lanark: His Critique of British Society", in: The Victorians and Social Protest, ed. by J. Butt and J. F. Clarke (Newton Abbot, 1971), p. 43; E. P. Thompson, The Making of the English Working Class (Harmondsworth, 1968), p. 861. 
exacting student of Owen and Owenism, J. F. C. Harrison, has described Owen's politics in terms of an ambivalent preference for both paternalism and egalitarianism. ${ }^{6}$ A judicious approach to Owen's political ideas and behaviour would thus do well to begin at a point of suspended judgment.

The present article will argue that the major problem with most of the foregoing interpretations is not that they are wrong - given their frequent use of notoriously imprecise terminology this is often difficult to state one way or the other -, but rather that, given the complexity of the problem, they have not searched sufficiently widely or deeply to be able to offer any form of definitive assessment of the political element in Owen's work. Equally if not more important, previous analyses have not seriously questioned the unpolitical nature of many of Owen's ideas; indeed Owen's failure to become involved in parliamentary-reform agitation has often served as the chief basis for the charge of "conservatism" against him. Owen's wish to transcend politics, however, is very significant for the history of political thought insofar as this tendency was shared by other nineteenth-century socialists (including Marx and Engels), thence becoming an important aspect of modern political ideas. Owen, however, has never been understood properly in terms of this attack upon traditional conceptions of politics, though the latter was central to his life's work.

Nonetheless, it will be argued here that while many of the central problems in interpreting Owen's politics do not resolve only into disagreements about the meaning of terms like "democracy" or "paternalism" (whose definitions tend to dictate whatever conclusions are ultimately drawn), even by contemporary standards of the meaning of "democracy", Owen's "despotic" tendencies have been heavily overemphasised. He was much more of a democrat in many of his plans and organisations than has been hitherto assumed. That his ultimate vision of society was "paternal" is beyond dispute, but a careful examination of Owen's use of this term reveals a more complex phenomenon than that usually associated with it. Owen did indeed deploy a familial model of politics, but the application of this model to both his interim and final visions of government has never been clarified, especially in terms of what is interpreted here as a sincere attempt to resolve what Owen took to be the greatest political problem of the day, the antipathy (as expressed at the theoretical level) between the principles of aristocracy and democracy. Finally, it will be argued that while Owen must ultimately be seen as a

${ }^{6}$ L. Jones, The Life, Times, and Labours of Robert Owen, 2nd ed. (London, 1895), p. 213 ; J. F. C. Harrison, Robert Owen and the Owenites in Britain and America (London, 1969), p. 76. 
utopian critic of democracy, he also felt that in superseding given democratic forms, such as elections, this was a positive advance upon democratic goals, not a retreat from them. Owen did intend to abolish "politics", but in so doing it was precisely arbitrary and unwarranted power that he sought to replace. The systems which he proposed to substitute for existing political processes were moreover much more a part of existing democratic theory than has been recognised previously. Hence even Owen's wish to supersede politics took place within a language and conceptual framework which was itself an important strand of the history of political thought, and indeed in America also contemporary political debate.

My argument in this article is divided into four sections. Firstly, the political element in Owen's plans during the first stage of his communitarian career (1816-34) is considered, as well as the context of this early anti-democratic reputation. Next, Owen's analysis of the root of political conflict in terms of his opposition to individualism (both moral and economic), the existing family, and class systems is characterised. The reconstitution of the family model and the development of the aetatic or gerontocratic system of social organisation is discussed, and interpreted in terms of Owen's wish to supersede the principles of both aristocracy and democracy. Thirdly, the practice of "elective paternal government" during the years of the principal Owenite organisations is analysed, and Owen's attitude towards the Charter and its proponents considered. Finally, an account is given of the "federalist" ideas put forward by Owen in relation to an eventual world of communities, and an interpretation is offered of the countervailing tendencies toward state centralisation in his plans and ideas.

1. The architecture of circumstances: The political element in Owen's plans, 1816-34

It has often been said that it was Owen's experience at New Lanark that gave him the confidence and inclination to revolutionise the world. The mills by the Clyde made Owen a rich man; his infant school and model factory village added fame, and helped to cement an already fixed view that his educational schemes were absolutely correct, and that "any character might be formed by applying the proper means", as it was put in $1812 .^{7}$

There are two aspects of this experience that are relevant to any understanding of Owen's political outlook. The first is the simple, and well-

7 R. Owen, A Statement Regarding the New Lanark Establishment (Glasgow, 1812), p. 4. 
known relation between the theory that character is essentially formed by external circumstances and the educator who helps form these circumstances, or who, in Owen's term, "governs" them as their "architect". "Having discovered that individuals were always formed by the circumstances [...] around them", Owen said on his first visit to America, "my practice was to govern the circumstances; and thus by means imperceptible and unknown to the individuals, I formed them, to the extent I could control the circumstances, into what I wish them to become; and in this manner were the beneficial changes effected in the population under my care."8 The identification of "government" with the task of education is thus at the root of the paternal ideal familiarly associated with Owen. Less well-known is the fact that, while Owen legislated at New Lanark, he was not equally judge and jury. By regulations laid down in 1800 , the village was divided into groups of houses, each called "neighbourhood divisions". Once a year the heads of households met to choose a "principal", and these principals from each group then chose twelve jurors to sit monthly for one year, hearing and judging upon all cases brought before them concerning the internal order of the community. ${ }^{9}$ Owen may indeed have begun with a paternal foundation - although we will see that this term does not have the same meaning in all his schemes -, but even here a system of indirect household suffrage guaranteed a measure of self-government and mitigated the need for the assistance of other governing authorities. This was a balance which, in terms of his interim forms of government, Owen sought to maintain throughout his career.

Owen's first detailed plea to the public, the New View of Society or Essays on the Principle of the Formation of the Human Character (1813), in essence asked the government (especially in the fourth essay) to apply some of the chief principles of New Lanark to the nation at large. If the end of government was to make the governed happy, gin shops, state lotteries, religious tests and other harmful laws should be ended. Duties on liquor ought to be increased so as to exceed the means of ordinary consumption. Seminaries should be set up to train teachers for a new educational branch

8 "Mr. Owen's Discourse on a New System of Society", in: O. C. Johnson, Robert Owen in the United States (New York, 1970), p. 27; R. Owen, Report of the Proceedings at the Several Public Meetings Held in Dublin (Dublin, 1823), pp. 14-15. On the relation of Owen's educational theories to the development of the British working-class movement, see M. Vester, Die Entstehung des Proletariats als Lernprozess (Frankfort-on-the-Main, 1970), pp. 187-233.

9 The original regulations are reprinted in R. Owen, The New Existence of Man Upon the Earth (London, 1854), V, pp. ix-xi. 
of government. Public works should be promoted in the event of distress, but otherwise the government should not directly employ individuals, but only provide training schemes to aid private employment. A reform in the condition of the poor was Owen's principal aim; all other reforms would have to wait "for some time to come". There is thus much that is political in the New View, in the sense of an appeal for the expansion of governmental activity. Parts of the programme conformed to the views of many political radicals, such as the ending of religious tests and the inception of a system of national education. In other aspects, such as taxes upon drink, a clear divergence was evident. ${ }^{10}$

It was during the course of 1817 that Owen's momentum increased enormously, and his trajectory moved towards the system of universal communitarian life which within a decade would be known as "socialism". Owen's first plans were for pauper communities alone, and it was only in the face of significant resistance (much of which he brought on himself through his antipathy to established religions) that Owen came to believe that the well-being of the poor necessitated the transformation of the entire society. By the end of the summer he was able to publish an elaborate plan for three major types of communities (with literally hundreds of variations according to political and religious preference) grouped according to four class divisions. Of these four classes, the parish poor would be directly ruled by "properly instructed superintendents and assistants". Members of the second class (working classes without property) would be employed in the "voluntary independent associations" of the fourth class, those possessing capital of $£ 1,000-20,000$, and unwilling or unable to be productively occupied. Members of the fourth class, like those of the third class (working class with property of $£ 100-2,000$ ) would govern themselves by electing a general committee which would then choose seven subcommittees. The propertyless employees in fourth-class communities would not be eligible to be elected or to elect to the general committee of those communities, but would instead elect seven of their own number, who with one member from each of the sub-committees, would vote to choose a head for themselves. This committee would then "superintend all the arrangements and transactions between the employers and the employed". 11

IU Id., "A New View of Society", in A New View of Society and Other Writings, ed. by J. Butt (London, 1977), pp. 63-90, 36.

11 Id., "Further Development of the Plan for the Relief of the Poor and the Emancipation of Mankind", ibid., pp. 228-31. 
Also established at this time was the thesis which was to become the basis not only for Owen's principle of future governments, but also for the entire reorganisation of society: rule by age group, or what Owen was later to term the "educational principle of government". This will be discussed in greater detail below; at this point it is necessary only to note that the immediate application of this idea appears to stem from two principal sources: the seventeenth-century Quaker John Bellers's suggestion that at the age of 60 all members of his proposed "Colledge" (with which plan Owen was very impressed) might become supervisors, and Owen's own resolute antipathy to the practice of elections as a divisive political exercise, which he may have considered more seriously at this time, and which led him to seek some means of avoiding them. Here Owen's proposed resolution of the latter problem was that

Each village will ultimately be governed by a committee of all its own members, from 40 to 50 years of age, or, should this number be too numerous, it may be composed of all from 45 to 50 years of age; which would form a permanent, experienced, local government, never opposed to, but always in closest union with, each individual governed. This Committee, through its oldest member, might communicate directly with the Government, and the utmost harmony be thus established between the executive, the legislature, and the people. ${ }^{12}$

During this period Owen was under attack, as we have seen, by radicals for his conservatism. Conservatives of various types, too, began to see the implications of his plans for their own position, and started opposing him as a radical. As John Bone put it, Owen was now in the unenviable position of one whom "the reformists call an aristocrat, the aristocrats a Jacobin". Owen's natural inclination was to assuage both sides by suggesting that his plan would realise the hopes of each and the fears of neither. To conservatives he was able to point to his earlier suggestion that it was "absolutely necessary to support the old systems and institutions under which we live until another system and another arrangement of society shall be proved by practice to be essentially superior", and to his reminders to workingclass audiences (such as that at New Lanark) that they should "still regard it as [their] duty to pay respect and submission to what is established". To the radicals he not only implied that political changes would arrive too late to aid those already verging upon starvation, but also that his plan, rather than increasing the powers of the government, would enhance that of the

12 Id., "Address Delivered at the City of London Tavern on Thursday, August 21. 1817", ibid., p. 218. Bellers is identified with this general scheme at p. 213. Owen reprinted his Proposals for Establishing a Colledge of Industry (1696) the following year. See p. 16 of the original edition for Bellers's comments on supervision at age 60 . 
people, "because in reality, as well as in theory, every person will become qualified to chuse his own representative". ${ }^{13}$

In the next few years, though his plan was developed in various other dramatic respects, Owen's political principles did not evolve to any noticeable extent. In the famous Report to the County of Lanark (1820) he was content to repeat that the government of communities would depend upon those who founded them, and that those founded by the working and middle classes should govern themselves. A rather more important discussion in this work, as we will see in the next section, concerned Owen's identification of the division of labour as the cause of a division of interests, and hence as a principal root of social and political conflict. To the British and Foreign Philanthropic Society, founded to raise funds, Owen expounded more precisely on the rules for government by capital investors. Until the capital raised for commencing a community was repaid, a governing committee chosen annually would consist of eight members who had invested $£ 100$ or more, and four from the rest of the community. Later that same (or in the following) year, however, he suggested that in the first instance a governing committee might simply be appointed by those who had furnished the capital. This was apparently in response to the possibility that a very small number of capitalists might be able to underwrite the whole enterprise. ${ }^{14}$

Owen's first communitarian experiment at New Harmony, Indiana, while it seems to have soured him on democratic practice run wild, nonetheless provoked a considerable amount of democratic rhetoric from him, and ultimately, as we will see below in reference to Owen's views of the state, provided him with a democratic language for the ultimate framework of his communitarian plans. At his first address in Washington DC in February 1825, Owen was careful to distinguish his own goals from those of political revolutionaries, but he still phrased this in such a way (as he would not often publicly do in the future) as to praise American political institutions.

By a hard struggle you have obtained political liberty, but you have yet to acquire real mental liberty, and if you cannot possess yourselves of it, your

13 The Age of Civilization, 11 April 1818, p. 80; R. Owen, "An Address to the Inhabitants of New Lanark", in A New View of Society and Other Writings, op. cit., p. 118; The Mirror of Truth, 1 October 1817, p. 8; 7 November, p. 59.

14 R. Owen, "Report to the County of Lanark", in A New View of Society and Other Writings, p. 287; Proceedings of the First General Meeting of the British and Foreign Philanthropic Society (London, 1822), pp. 46-56; Permanent Relief for the British Agricultural and Manufacturing Labourers and the Irish Peasantry (London, 1822 or 1823), p. 9 
political liberty will be precarious and of much less value. The attainment of political liberty is, however, a necessary step towards the acquirement of real mental liberty, and as you have obtained the former, I have come here to assist you to secure the latter. For, without mental liberty, there can be no sincerity, and, without sincerity, devoid of all deception, there can be no real virtue or happiness among mankind. ${ }^{15}$

The principle of communities, Owen explained several weeks later, fitted well into the American system.

These communities are in complete union with the principles on which the constitution of this country is founded. The constitution is essentially a government of the union of independent states, acting together for their mutual benefit. The new communities would stand in the same relation to their respective state governments, that the States now do to the General Governments, and, in consequence, the arduous duties of both will be, most probably, materially diminished. ${ }^{16}$

There yet remained, however, as there always would for Owen, the problem of the interim government of the communities themselves. On his first trip to the United States Owen published at least three separate plans of community government. The first was merely a repetition of the British and Foreign Philanthropic Society scheme of two-thirds-majority rule by holders of capital. The second suggested an elected government of those "best qualified" to rule, and the third a committee of twelve elected by all. The outcome of the governmental anarchy at New Harmony, however, was that Owen was given virtually absolute power over two of the three communities then existing. The earlier "Preliminary Society" had gone against his wishes in unanimously voting to establish full community of property. Frequent changes of governmental form had led to the formation of three separate communities, two of whose pecuniary difficulties provoked the call of assistance to Owen, who, however, was unable to hold the project as a whole together, and finally returned to England. ${ }^{17}$ The failure of the first attempt seems to have confirmed in Owen's mind the inadequacies of pre-existing democratic mechanisms, and more specifically the need for an equal education according to age, throughout

15 "Mr. Owen's Discourse on a New System of Society", loc. cit., p. 31. See the New Harmony Gazette, 25 April 1827, p. 234. A general history of government at New Harmony is given ibid., 28 March, pp. 206-07. See also A. E. Bestor, Backwoods Utopias: The Sectarian and Owenite Phases of Communitarian Socialism in America, 1663-1829 (Philadelphia, 1950), pp. 160-202.

16 "Mr. Owen's Second Discourse on a New System of Society", in: Johnson, Robert Owen in the United States, op. cit., pp. 53, 56; New Harmony Gazette, 7 February 1827, p. 145; 21 February, p. 161.

17 Ibid., 28 March, p. 206. 
the community, before an attempt at genuine equality could be made. Education was thus not only the key to the future, when the world would "be governed through education alone, since all other government will then become useless and unnecessary"; it seemed also to have much to do with the interim stage before this ideal could be attained. ${ }^{18}$

When Owen originally departed for the New World, he had left behind him a few determined disciples, and the seeds of another community experiment (Orbiston, with which he personally had little involvement), which withered at an early age. When he returned, Owen found a lively and rapidly expanding co-operative movement, which in some centres was already forging links with both political radicalism and trade unionism. The rapid development of this movement seemed to exemplify the potential success of a decentralised, essentially working-class co-operative effort. It had its own societies, journals (principally the London Cooperative Magazine, which ran from 1826 to 1830), and had found in William Thompson both an intelligent economist and a more forthright and identifiably radical democratic theorist than Owen was ever to be. It was Owen's attempt to draw the reins upon this movement, and to guide it into what he regarded as the proper direction, which led to his reputation among many working-class leaders as a despot, and which engendered a degree of mistrust which was never to be overcome.

One occasion more than any other led the leaders of the new movement to regard Owen warily. At the third co-operative congress, held in April 1832 , four separate but related incidents alienated almost everyone present from Owen. Firstly, responding to Owen's "Address to the Governments of Europe and America", a delegate named Watkins objected to the idea that co-operators were "indifferent to the form of government" under which their endeavours began. Two other delegates, Mandley and Petrie, interpreted this to mean that if governments would not support them, "the working classes would do all they wanted for themselves". But Owen, ignoring this charitable reading of his sentiments, and apparently deliberately trying to be difficult, insisted that

despotic governments were frequently found to be better than what were called democratic. In the countries where those governments existed, the industrious classes were not found in such misery and destitution as in their country; and therefore, on this ground, there was no reason to dislike despotisms. As far as the co-operative system was concerned, it was of no

18 Ibid., 23 August 1826, p. 383: 10 January 1827, p. 113; London Co-operative Magazine, I March 1830, p. 37. For a bitterly critical reflection upon Owen's government at New Harmony, see P. Brown, Twelve Months in New Harmony (Cincinnati. 1827). 
consequence whether governments were despotic or not. In asking for an entire change in social relations, it must be seen that change could be better effected by an existing government, than by one to be newly introduced. ${ }^{19}$

This was not a very persuasive argument as far as most of those present were concerned, but Owen had not yet finished. The main debate at the congress concerned a choice between a small-scale community plan put forward by William Thompson, and a far more grandiose and expensive scheme submitted by Owen. Whatever happened, Owen said, "to ensure success, a complete unity must pervade the whole - committees and majorities would never answer; there would be too much confusion. He had found, by thirty years experience, that people could not act for themselves in a community. There must be some conducting head." William Lovett objected that this "savoured [...j of despotism", and while Owen stated that he was opposed to despotism, he nonetheless insisted that "one mind must direct". ${ }^{20}$

The third incident took place in a smaller committee, where one of Owen's amendments to a proposed circular was rejected. Owen insisted on its inclusion, however, and finally persuaded the printer to insert it. Lovett and others then went to ask Owen if this was not despotic. Lovett later described Owen's reply: "With the greatest composure he answered that it evidently was despotic; but as we, as well as the committee that sent us, were all ignorant of his plans, and of the objects he had in view, we must consent to be ruled by despots till we had acquired sufficient knowledge to govern ourselves." 21 By far the most provocative action by Owen, however, came when a committee voted in favour of William Thompson's community plans rather than his own. Lovett called Owen's response "a bombshell", and William Carpenter even omitted it from his published report of the proceedings. If the committee insisted on accepting Thompson's plan, Owen said, all present marriage connections would have to be dissolved. This appears to have been a rather senseless and spiteful form of retaliation on Owen's part, but it failed to have the effect he intended, since the committee did not alter their decision. ${ }^{22}$

The next few years saw little change in the perceptions established at the 1832 congress. At his Equitable Labour Exchange Bazaar, Owen gave the governor and his five directors (who were however elected by ballot) full

19 Proceedings of the Third Co-operative Congress (London, 1832), pp. 53-54.

20 Ibid., p. 93.

21 W. Lovett, The Life and Struggles of William Lovett (London, 1967), pp. 40-41.

$22 \mathrm{Ibid}$. For other accounts of Owen's behaviour at this congress, see G. J. Holyoake, The History of Co-operation (2 vols; London, 1906), I, p. 120, and R. K. P. Pankhurst, William Thompson (London, 1954), pp. 157-79. 
power to hire, fire, and manage affairs as they pleased, a form of government which the London co-operator Benjamin Warden called "of a perfectly despotic nature". ${ }^{23}$ During Owen's brief connection with the Grand National Consolidated Trades' Union, the high point of his contact with large-scale independent working-class organisations, he was several times accused of acting in a dictatorial fashion. In the name of the GNCTU executive, Owen asked James Morrison, editor of the union paper Pioneer, to surrender control over its contents to the former body, and was refused, with Morrison pointedly telling Owen that "the sweetest despotism" was "that of universal love". ${ }^{24}$ J. E. Smith, editor of Owen's Crisis, had similar complaints when Owen objected to certain of his articles on the GNCTU executive, although it is evident that Smith was deliberately trying to suppress Owen's writings and his influence while employed on the paper. Owen's most public attempt to surpass his nominal authority came at the end of the great London march in support of the "Tolpuddle martyrs" in April 1834. Owen apparently took a short cut in order to pre-empt the official GNCTU delegation to Lord Melbourne, but, not being part of that delegation, he was denied entry, and when the deiegation finally arrived Owen was forced to leave before they could gain entry to Melbourne. ${ }^{25}$

Throughout most of this period, too, Owen remained opposed to the immediate granting of universal suffrage in Britain, a position which never failed to arouse the ire of Bronterre O'Brien, editor of the Poor Man's Guardian. $^{26}$ In 1830 Owen had even written that the French should support the hereditary monarchy rather than the republican or other parties. ${ }^{27}$ His published political programmes in these years, however, can be classified as "liberal" in virtually every other respect except their silence on the suffrage question and their advocacy of widespread economic intervention. When proposing himself as a Member of Parliament in 1832, Owen included a seven-point plan which encompassed a graduated property tax equal to the national expenditure, the abolition of all other taxes, free trade with all the world, national education and national employment for all who desired them, liberty of speech and writing, and religious freedom. He also promised to give political freedom to all British dependencies, to enable them to govern themselves. This was in effect

23 Rules and Regulations of the Equitable Labour Exchange (London, 1832), pp. 4-6;

Proceedings of the Third Co-operative Congress, p. 47.

${ }^{24}$ Pioneer, 7 June 1834, p. 393.

25 Crisis, 19 April 1834, pp. 12-13; Pioneer, 26 April, pp. 317-19: A. Somerville, Autobiography of a Working Man (London, 1967), p. 286.

26 See for example Owen's comments in the Poor Man's Guardian, 14 March 1835, pp. 460-61, and O'Brien's response ibid.. 21 March, pp. 465-68.

27 Trades' Newspaper and Mechanics Weekly Gazette, 21 August 1830. 
Owen's first formal political programme during the mature years of the Owenite movement, and is as such an important indication on his stand on a range of political issues. ${ }^{28}$

We have so far seen that Owen can by no means be called a "Radical Reformer" (in the contemporary parliamentary sense of the term) during the first fifteen years of organised Owenite agitation. His behaviour on the contrary had engendered the strong suspicion that he sought to insist upon conformity to his own inclinations, whatever he was involved with. On occasion he was domineering and thoroughly egotistical. Yet we have also seen that there were important democratic elements in both his activities and plans. Owen often disregarded the wishes of a majority of his would-be associates, but he was also capable of insisting that his election as Grand Master of the GNCTU be approved by two-thirds of the trades-union lodges, and of writing, with reference to communitarian government, that "It is the natural right of man, that he should have his equal and just share in the direction and management of those concerns." 29 Nor, after all, should such sentiments be taken as merely rhetoric, though Owen did in fact sometimes demonstrate a certain political acumen by varying his approach according to the audience he was dealing with. What exactly Owen meant in such statements, however, can only be clarified by considering what he took the first principles of politics to be.

\section{2. "The germ of all party": Owen's analysis of politics}

As is the case with most other writers, Owen's political ideas only begin to make sense when seen in the larger context of his thought as a whole. Owen did indeed regard political struggles as epiphenomenal manifestations of deeper principles of conflict, but it is a reduction and violation of the complexity of his thought to assert, as for example Cole has done, that this meant that he "conceived of the world of politics as no more than an emanation from the real world of economic relationships". ${ }^{30}$ There is certainly an important element of truth in this, but on the whole Owen was trying to convey far more in his general analysis of social dissension. The sources of disunion were political and religious as well as economic, and when, in 1816, Owen announced that his aim was "to withdraw the germ of

28 Robert Owen's Reply to the Question, "What Would You Do If You Were Prime Minister?" (London, 1832), pp. 12,3. Owen had also run for Parliament twice in 1819-20. See Podmore, Robert Owen, op. cit., p. 264, for details.

29 New Moral World, 17 October 1835, pp. 401-03; 24 October, p. 409; Robert Owen's Opening Speech, and His Reply to the Rev. Alex. Campbell in the Recent Public Discussion in Cincinnati (Cincinnati, 1829), pp. 141-42.

${ }^{30}$ G. D. H. Cole, The Life of Robert Owen, 3rd ed. (London, 1965), p. 11. 
all party from society", the "germ" he had in mind referred as much to an educational as an economic theory, for education, needless to say, was for Owen the source of all forms of social behaviour, with any "original nature" playing virtually no role whatsoever. ${ }^{31}$

It is not necessary to search far in Owen's writings for this original principle of conflict; he repeated it literally hundreds of thousands of times, straining as a result the patience of both his listeners and later interpreters: "The character of man is formed for him, and not by him." This thesis, to some extent, is merely a crude assertion in support of the environmental side of the "nature against nurture" debate. But to dismiss it as no more than this is to disregard the explanatory capacity and perlocutionary significance invested in the theory and Owen's statements of it, and hence to ignore the particular ways in which he deployed it. The explanation of conflict is the most important of these, and it is worth quoting at length from one of Owen's clearest statements of this.

The notion that man forms his own character [. . ] excites feelings at once opposed to charity and good will, and gives a wrong direction to our whole proceedings. By diverting the attention of society from the circumstances in which the individual is placed, and which really determine whether his character shall be well or ill-formed, it leads us - not to adopt measures of effectual prevention - but rather to permit the crime and afterwards punish the victim, who had been urged to the commission of it, by circumstances over which he could have no control, but which society might have removed from around him. It leads us to approach our fellow-creatures with a disposition to regard their characters, opinion, and conduct, - not as resulting from the causes which do really and necessarily make them what they are, but as attributable to themselves individually, as if they were beings independent of motives - as if they could act without a cause for acting - as if, in fact, they not only created themselves at birth, but had individually a power to pre-arrange all the circumstances which should afterwards surround them. It fills the mind, therefore, with all those notions which create feelings of displeasure, anger, and hatred, between man and man. It is, in consequence, the source of all the divisions, the party animosities, and the separate and contending interests, which afflict our species. It opposes, at every step, all attempts at conciliation and improvement. $^{32}$

What is important to us here is Owen's insistence that "the notion that the character is formed by the Individual [...] is the foundation of the

31 Owen, "An Address to the Inhabitants of New Lanark", loc. cit., p. 106.

32 Id., Report of the Proceedings at the Several Public Meetings Held in Dublin, op. cit., pp. $55-56$. 
individual system which, with very partial exceptions, has hitherto prevailed over the earth." ${ }^{33}$ The individual system, in turn, was for Owen most popularly defined in terms of the theory of individual interest, and more specifically the view "that man can provide better for himself, and more advantageously for the public, when left to his own individual exertions, opposed to, and in competition with his fellows, than when aided by any social arrangement, which shall unite his interests individually and generally with society". ${ }^{34}$ The "principle of individual interest", which Owen particularly accused the political economists of propagating, was thus held responsible for "all the divisions of mankind, the endless errors and mischiefs of class, sect, party, and of national antipathies, creating the angry and malevolent passions, and all the crimes and misery with which the human race have been hitherto afflicted". ${ }^{35}$ These statements essentially constituted the theoretical foundation of the meaning of the word "social" when it came to be used, as "socialism", to describe Owen's movement. ${ }^{36}$ How, then, does this relate more specifically to Owen's political ideas?

There are a number of different ways to approach this question. Firstly, Owen regarded all governments as rooted in the individual principle insofar as they ruled, through force and fraud, by pursuing the effects of disunion, while failing to remove the causes which produced all injurious effects. A belief in free will led them to punish where punishment merely forged more strongly the chain of effects created by malevolent circumstances. Hence Owen was led to contrast "government by circumstances" (or "by nature") to government "by laws and precepts" (or by human beings, i.e. arbitrarily), where the first would "ever produce the effects intended while the latter are calculated only to create disappointment". ${ }^{37}$ Giving individual rewards and punishments, and especially enshrining these in law, merely functioned as a "direct bribe" which

33 Ibid., p. 152.

34 Owen, "Report to the County of Lanark", loc. cit., p. 269.

35 Ibid.

36 "Socialism" first occurs in the London Co-operative Magazine, November 1827, p. 509 , note. The Oxford English Dictionary gives the first English usage of "individualism" as 1840 , and presumes it to be taken from the French. I have found it used in English as early as 1834. however, and it is obvious that the conceptual opposition between "socialism" and "individualism" had begun to assume a new form as early as the turn of the century. On the new "social" language of the early-nineteenth-century working-class movements, see in particular G. Stedman Jones, "Rethinking Chartism", in: Studies in English Working Class Radicalism and Culture, 1830-1860, ed. by D. Thompson and J. A. Epstein (forthcoming, 1982).

37 R. Owen, A Development of the Principles and Plans on which to establish Self-Supporting Home Colonies (London, 1841), p. 34. 
counteracted the system of rewarding and punishing inscribed in the natural order of both society and the individual psyche. A natural or necessitarian education would thus render a punitive government superfluous, and this Owen regarded as the only true path to personal liberty.

The real lovers of liberty will discover that it is by these means only that rational liberty can ever be acquired or permanently enjoyed. In the exact proportion in which individuals shall be well-trained from infancy, and placed under circumstances which they can well govern themselves, may the restraints of general government be safely withdrawn; and as real knowledge and improvements advance among the mass of the population of the world, these restraints will be withdrawn, because no arbitrary power will then be able to restrain them. ${ }^{38}$

All of this, however, required the acceptance of necessitarian principles of government: "There never was, there cannot be permanency in any plan, scheme, system or arrangement for the government of mankind, founded on the notions of man's free will." 39

Secondly, the way in which existing governments were organised was intrinsically bound up with the functioning of the individual principle in society as a whole.

The interest of those who govern has ever appeared to be, and under the present systems ever will appear to be, opposed to the interest of those whom they govern. Law and taxation, as these are now necessarily administered, are evils of the greatest magnitude. They are a curse to every part of society; but while man remains individualized they must continue, and both must unavoidably still increase in magnitude of evil. ${ }^{40}$

The two prevalent principles of government in contemporary society, monarchy and aristocracy, were also "necessarily produced by the individualized state of society". ${ }^{41}$ Each form of government was defective as such, although Owen assigned separate reasons for denying their utility.

It is now evident, that no people can be virtuous, intelligent and happy under any despotic or elective form of government, or under any modification of them. These forms must necessarily produce evil continually. Monarchy is defective in principle, on account of the uncertain character of the sovereign, as well as the extreme inequality it produces in the condition

38 Id., letter to the Times, 29 May 1817, excerpted in the Evening Mail, 30 May; id., Lectures on an Entire New State of Society (London, 1830), p. 61; Permanent Relief, op. cit., p. 4.

39 Robert Owen's Opening Speech, op. cit., p. 214.

40 Owen, "Address Delivered at the City of London Tavern", loc. cit., p. 218.

41 Id., Lectures on an Entire New State, op. cit., p. 148. 
of the governed. The elective principle is equally defective, under the old arrangements of society, on account of the corruption of morals and the unceasing bad feelings which it engenders. And any combination of these two modes of government will necessarily partake of the evils of both. ${ }^{42}$

Owen's main argument against democratic forms of government, then, was the process of election or selection by which governments were chosen. Having observed the principles of democracy at work in America, Owen wrote in 1835 ,

I saw they were well calculated to mitigate some evils of election to office, but they produced many others, equally pernicious, by continually calling the worst feelings of our nature into constant action, proving to me, what I had long known, that there will never be a permanent, prosperous, or good state of society, as long as the election principle to the offices of government shall be maintained. ${ }^{43}$

The process of electioneering was merely one incessant series of personal contests, "which must produce a state of never-ending confusion". ${ }^{44}$ While human behaviour and character remained the same, it mattered little who was in government; their actions in power would be similar.

If those who are poor to-day become powerful and succeed to the government to-morrow, these same individuals, who were poor, will, through their power, become rich, and they will then oppress those who may become poor by the change, and act just as the rich and the powerful have always done to the poor from the beginning to the present moment. ${ }^{45}$

For these same reasons the tendency of revolutions was only to "make democrats into aristocrats". The answer, rather, was:

Instead of thus contending against the rich and powerful individuals, who, for the time being, govern, and who are ever what riches and power make men so placed, the contest should be against the system which makes some men rich and powerful, and others poor and weak, greatly to the disadvantage not only of the extreme rich and poor, but of all classes of persons between those extremes. ${ }^{46}$

It followed, of course, that Owen rejected the idea of a party as the model for either the society of the new world, or as a vehicle for getting there.

42 Robert Owen's Opening Speech, p. 43.

43 Poor Man's Guardian, 7 November 1835, p. 731.

${ }^{44} \mathrm{R}$. Owen, Public Discussion Between Robert Owen and the Rev. J. H. Roebuck (London, 1837), p. 115.

45 New Moral World, 3 April 1835, p. 178.

${ }^{46} \mathrm{R}$. Owen, A Dialogue between the Founder of the Association of All Classes of All Nations and a Stranger (Leeds, 1838), p. 19. 
Parties were merely "the necessary effects of ignorance of human nature, of society, and of common sense". ${ }^{47}$

The model which Owen did settle upon (and which to some extent was in his mind all of the time, though it did change and develop) was that of the family. We will see in the next section how Owen set about adapting this model for use as a temporary, interim form of government. First it is necessary to consider the essential parts of the model as a whole, why Owen chose it, what it meant to him, and what problems he felt would be solved by its implementation.

Had it not been for the need rationally to solve the problem of authority, Owen probably never would have chosen the image of the family as a model in the first place, for he was generally very hostile to contemporary forms of family life. There were both individual and social reasons for this. Firstly, Owen condemned the system of marriage in which motives of personal gain often played a part, where the wife's rights and social roles were severely circumscribed, and where the difficulty of obtaining a divorce, coupled with a social double standard in the treatment of infidelities, engendered both protracted mutual hostilities and pervasive duplicity. Simply taken as a relationship between two people, marriage was a virtually unrivalled source of immorality: "there is, perhaps, now more deception expressed in look, manner and words, all forming language, between the husbands and wives, made such by the Priesthood of the world, than there is between any other parties throughout the whole of society, not even excepting the present buyers and sellers of goods or money for pecuniary profit." The contemporary system of marriage was thus responsible for all prostitution (indeed Owen often equated the two), as well as a host of other vile crimes. ${ }^{48}$ Secondly, Owen held the social value of "single-family arrangements" to be entirely negligible. As educational institutions they could more properly be termed disastrous, for it was here that children first came to learn the meaning of selfishness.

The single-family arrangements are hostile to the cultivation in children of any of the superior and ennobling qualities of human nature. They are trained by them to acquire all the most mean and ignorant selfish feelings that

47 Robert Owen's Journal, 8 November 1851, p. 12. See also ibid., 27 March 1852, p. 170. where Owen contrasts party and national interests at some length.

48 R. Owen, The Marriage System of the New Moral World (Leeds, 1838), pp. 25-27. For a general discussion of Owen's view of marriage, see J. Saville, "Robert Owen on the Family and Marriage System of the Old Immoral World", in: Rebels and Their Causes, ed. by M. Cornforth (London, 1978), pp. 107-21. An extremely comprehensive treatment can be found in B. Taylor, "The Feminist Theory and Practice of the Owenite Socialist Movement in Britain, 1820-1845" (Ph.D. thesis, Sussex University, 1980). 
can be generated in the human character. The children within these dens of selfishness and hypocrisy are taught to consider their own individual family their own world, and that it is the duty and interest of all within this little orb to do whatever they can to promote the advantages of all the legitimate members of it. With these persons, it is $m y$ house, $m y$ wife, $m y$ estate, $m y$ children, or $m y$ husband, our estate, and our children; or $m y$ parents, $m y$ brothers, $m y$ sisters, and our house and property. This family party is trained to consider it quite right, and a superior mode of acting, for each member of it to seek, by all fair means, as almost any means, except direct robbery, are termed, to increase the wealth, honour, and privileges of the family and of every individual member of it. Now, all other families are so placed and taught that they also feel a similar desire to promote, by the same fair means. as they are called, the interest of every individual relative within their family circle. And thus is every family made a little exclusive world seeking its own advantage, regardless of and to a great extent in direct opposition to all other families, having the same objects in view; and, consequently, there is a more or less direct competition between all families. ${ }^{49}$

It was this form of the family, then, which thus contained the "germ of party", taking the latter idea simply to mean the origins of selfishness and hence personal antagonism. Building a community with such materials, Owen felt, was essentially impossible. Whatever appeals might be made to individually rational people would merely be subverted by the moral standard of evaluation immediately given in the nature of the family institution, "as the interest of private families is quite opposed to that of a number of equally free and intelligent individuals".50 Owen had apparently encountered this problem first at New Harmony, where in an 1826 lecture he gave an unusually practical example of how it functioned in everyday activity, while also pointing towards his own solution.

We all know that when a family party converses together, they speak freely upon subjects which as soon as a stranger accidentally enters amongst them he never hears. Then again, there are perhaps three, four, five or six acquaintances with whom the family is intimate, and when they join the family, another little circle of ideas for conversation becomes common between the parties, but yet different from the family circle of ideas: an ordinary acquaintance appears, and that conversation also ceases: - the party begin to talk upon some general common topic in which probably not one takes any interest. But by a common education, you may all acquire the same general and particular ideas and feelings: consequently, into whatever circle you enter, you would still be in your family circle, and would converse

49 New Moral World, 27 December 1834, p. 67. This text is from lectures given by Owen in 1834, which were reprinted, substantially unchanged, as The Marriage System of the New Moral World, op. cit.

50 Owen, The Marriage System, pp. 71-72. 
with each other as freely as with a husband, wife. or child. ${ }^{51}$

Thus it was in a sense one of the great paradoxes of Owen's system that to make individuals fully social, they must first be made fully individual, for it was only their wholly independent consideration of the problem of individual and social interests that would reveal this problem in all its clarity, divorced from the pressures of group adherence.

The new moral family, then, would bear little resemblance to its old immoral ancestor. Owen did, nonetheless, believe that there had been a significant historical antecedent for the united-interest family, and it is evidently this image, more than any other, which he sought to recreate in practice. Writing in 1850 , Owen described a period "eighty years ago", or just before the rise of the manufacturing system, when "the real comfort of farmers and their servants living with them - of tradesmen and their apprentices and journeymen, always forming one family, was greatly beyond any now experienced; and there was confidence, attachment, and happiness between these parties, arising from their equal position and friendly daily intercourse, unknown at present." ${ }^{2}$ It must, however, be emphasised that, while such imagery conjures certain idyllic connotations, Owen never planned or wished that society should return to an epoch in which hierarchies had been based upon principles other than those of age. Society ideally would be composed only of "parents, brothers and sisters throughout the world, animated by the strongest family affections", but such a family would ultimately bear as little relation to history as it did to blood; it would instead represent a distillation of all of (what Owen took to be) the best qualities of both social and familial communalism. ${ }^{53}$

Far more important than the historicity of this image was Owen's idea that a common interest was the essential characteristic of the future social family. The principle of individual interests was for Owen the source, as we have seen, of all divisions between people. Such competition would only be overcome "when the whole interest of the individual, and of society is identified as one family, whose powers, faculties, properties, and possessions shall be directly applied to promote the well-doing and happiness of each individual, without partiality, according to the peculiar constitution of each member of this large family". ${ }^{54}$ But Owen was not

51 New Harmony Gazette, 30 August 1826, p. 390.

52 Robert Owen's Weekly Letters to the Human Race, IV (1850), pp. 33-34.

53 A Full Account of the Farewell Festival Given to Robert Owen on his Departure for America (London, 1844), p. 4.

54 R. Owen, The Catechism of the New Moral World, 2nd ed. (Leeds, 1838), p. 7. An earlier treatment of this theme is in G. Claeys and P. Kerr, "Mechanical Political Economy", in: Cambridge Journal of Economics, V (1981), pp. 268-71. 
so simple-minded as to suppose that it was possible merely to impose the paternal model of government in order to reconcile interests which previously had been deeply divided. For the paternal system included not only a form of government, but also (when its details had been worked out) a mode of social organisation without which the form of government could not survive according to the definition Owen had assigned to it, which guaranteed to all the benefits of equal rights, equal education, and "pure" or "true" democracy. The paternal form of government could remain nominally democratic, in the sense that all of a certain age would form the government, and hence all would eventually rule, in any form of social organisation. But this, for Owen, remained nonetheless a recipe for chaos, because other sources of divided interest would still exist untouched, and hence in contradiction to the mode of rule.

The most important of these was occupation. In Owen's mind it was the maldistribution of labour which was the crux of class division, and which most essentially underlay political and social conflict. Society was divided into those who produced wealth and value, the productive classes, and those who did not, who either shirked labour entirely, or added nothing to the social value of the product even if, as in the case of the vast majority of middlemen, they did add to the market price of the product. Unless some single rational scheme of the division of labour were followed, government could still be used, preferentially, as a means for assisting others to avoid labour, and hence might still function (as Owen said the British Parliament did in 1835) as "a complicated machine, to enable the useless non-producer of wealth to enslave, and keep in ignorance and poverty, the actual producer of wealth". ${ }^{55}$ The only remedy for this was to provide for a government in which all of the governors were also producers, or, in Owen's solution, had been producers, such that the interest of governors and governed remained the same, and did not degenerate (as it had in the eyes of most contemporary radicals) into a hostile division between governing consumers (of taxes, hence labour) and governed producers.

Owen's final plan was for the division of society into eight age groups, in which each group would perform one major set of tasks at a given age, moving on to something else at the expiry of the assigned period, thereby permitting all to do and become all. Age would thus supplant class as the

55 New Moral World, 26 September 1835, p. 382 . For further treatment of the productive/unproductive distinction and its implications, see my "The Role of 'Unproductive Labour' in the Development of early British Socialist Theory: From Godwin to 1850", in: After Adam Smith: Essays on the Development of Political Economy in the early Nineteenth Century, ed. by I. Hont (Cambridge, forthcoming). 
principle for the organisation of labour, with the young, adult and mature periods of age replacing what Owen took to be the functions of the working, middle and upper classes. The first class (as Owen called these groups), from birth to age 5 , would be involved almost wholly with education. The second (5-10 years old) would in addition assist with domestic labour. In the third class (10-15 years old), the first two years would be spent directing those aged 7-10 in their "domestic exercises", while the final three years would be devoted to acquiring "a knowledge of the principles and practices of the more advanced useful arts of life", being instructed by the members of the class above them (aged 15-20), who would be engaged in production as well. The fifth class (20-25) would supervise all branches of production and education, the sixth (25-30) preserve and distribute wealth, and the seventh (30-40) govern the "home department" of the community. The eighth and final class, those aged 40-60, would conduct all foreign affairs. ${ }^{56}$ The net effect of this scheme, then, was to combine "in the same individual the producer, and the possessor of wealth, the communicator and the recipient of knowledge, the governor and the governed, to destroy the invidious distinctions that have split up the one great family of man into sections and classes". 57

There is no evidence, however, that Owen intended to implement such a scheme at the beginning of his social mission. Certainly it does not appear in his early plans. It would seem, rather, to have been the logical and natural outgrowth of both his early intentions and subsequent experiences. Its essential principle - the division by age - occurs first (in 1817) in the context of government only, as a means of overcoming the need for elections and of providing a fixed principle of authority. The further that Owen detached himself from any compromise with the old system, however, and the more he came to insist that both equality of education and equality of condition were prerequisites of successful community life, the more his initial hostility to the malevolence of a narrow technical division of labour became transformed into a general theory of the social, moral and political as well as technical division of labour. Proposals for an equality of condition are present in a number of Owen's early writings. Also evident as early as 1821 is the idea that age and experience (the two are presumed coincident) are the only just and natural distinctions, and

56 R. Owen, Six Lectures Delivered in Manchester, previous to the Discussion between Mr. Robert Owen and the Rev. J. H. Roebuck (Manchester, 1839), pp. 73-83; Robert Owen's Address, Delivered at the Meeting in St. Martin's Hall (London, 1855), p. 17. The first statement of this scheme was probably in 1835. See the New Moral World, 9 May 1835, p. 221.

57 New Moral World, 24 May, p. 388. 
that the only inequalities of the future will be those of age. ${ }^{58}$ It was apparently not until 1829 , however, that all of the necessary elements were assembled and formalised as a "Universal Code of Laws" for the future organisation of society, and it was established that "all shall pass through the same general routine of education, and domestic teaching, and employment" as well as government. ${ }^{59}$ This general concept, without the addition of many further ideas, was maintained during the labour-exchange and trades-union phases of the 1830's, and when Owen then returned more directly to communitarian planning, he finally elaborated what was to be his final, detailed plan of social organisation by age.

Owen's use of the language of politics in relation to his own paternal system now can be clarified more fully. Firstly, the paternal mode of government and social organisation represented the supersession of both of the principles, aristocracy and democracy, that Owen considered to have been the historical basis of all forms of government. Democracy, viewed in this sense, was "in practice essentially violent and selfish; always grasping for more territory nationally, and for more wealth individually, without knowing how rationally to use the one or the other" ${ }^{60}$ It was in Owen's experience merely a system of universal egoism reduced to political principle, which in its practical application tended in any case, as we have seen, to reproduce an aristocracy of new rulers with only a cosmetic change in the form of government to distinguish between the two systems. In virtually all of its manifestations in the old world, therefore, aristocracy too was unacceptable to Owen.

On the other hand, the paternal system was also a synthesis of what Owen assumed were the most valuable aspects of both democracy and aristocracy. "Under the best conditions of the most advanced nations", Owen wrote in 1846, "the natural rights of man are talked about, but are unknown in practice; democratic constitutions are spoken of and recommended, but a true democracy has yet to be established among the nations of the earth."61 "True democracy" did mean equal rights for all, but this phrase, to Owen, had to be given "a rational meaning", and could only include "equal rights at birth and through life".

58 Permanent Relief, p. 4; New Harmony Gazette, 7 February 1827, p. 146; 21 February, p. 161. The last cited work, entitled The Social System, was written about 1821, though it did not appear in print until 1826. See ibid., 22 November 1826, p. 63.

59 Robert Owen's Opening Speech, p. 49.

60 A Supplementary Appendix to the First Volume of the Life of Robert Owen (London. 1858), p. iii.

61 The Daily Union (New York), 11 March 1846, University of London Manuscript 578 (Pare Papers), f. 147. 
There are no "equal rights" when one, without individual merit, shall inherit large accumulated riches; while another, without individual demerit, shall be born to experience all the ills and crimes of poverty. There can be no "equal rights" when one, without individual merit, shall be carefully and expensively educated from birth: while another, without individual demerit, shall be uncared for and uneducated through life. There can be no "equal rights" when one, without individual merit, shall be placed from birth through life within superior circumstances. while another, without individual demerit, shall be placed from birth within the most deteriorating circumstances of man's creation. "Equal rights" consist in equal education and condition through life according to age. ${ }^{62}$

Understood as this form of equality, then, democracy could be recommended as the panacea for all political and social evils: "Without a full and complete equality, there can be no general permanent happiness, in fact no justice among men. It is the pure principle of democracy carried out to its full extent in practice, that can alone carry the human race onward toward the highest degree of perfection." 63 But within this scheme of equality, nonetheless, there ruled "nature's genuine and unopposed aristocracy", those aged 40-60, who through their experience and interest in the happiness of the governed, were naturally and rationally qualified to represent the "parental principle of governing", "the perfection of governing". ${ }^{64}$ The movement of history had been towards democracy as it was commonly understood, but would only cease developing when it had reached Owen's principle of government.

The despotic and the hereditary principles of governing are abandoned by the reflecting and intelligent Liberal, who now advocates the representative principle, in opposition to both: and this latter will for a time prevail: that is. until experience shall prove its evils in practice, and then it must give way to the only principle by which mankind can be well governed. This may be called the educational principle, and it will supersede the despotic. hereditary, and elective - the now popular principle among the liberal members of society. When, however, men can have minds formed for them, freed from the gross errors with which they have been filled by the present system, they will see clearly the everlasting evils which must attend the despotic, the hereditary, and the elective principles of governing: but it is necessary to pass through these three gradations, to arrive at the fourth, or true principle of government. ${ }^{65}$

62 New Moral World, 10 May 1845, p. 365.

${ }^{63}$ Spirit of the Age, 2 December 1848, p. 298.

${ }_{64}$ R. Owen, The Book of the New Moral World (London, 1842-44), VI, p. 64; Letter from Mr. Owen to the President and Members of the New York State Convention (New York, 1846), p. 26.

${ }^{65}$ New Moral World, 26 September 1835, p. 380. 
Movement towards this final stage, however, entailed a number of difficulties. These are best illustrated through an examination of Owen's practical handling of the problem of transitional government.

3. The practice of "elective paternal government" and the Chartist years, $1835-50$

The Association of All Classes of All Nations, founded in 1835, was essentially the first socialist organisation of any importance in which, throughout most of its history, Owen basically got his own way. From the beginning, wrote William Galpin, one of Owen's closest associates in this period, Owen "more or less superintended the general affairs" of the AACAN ${ }^{66}$ More than any other phase of early British socialism, this was Owen's personal creation: his entire reputation (there was little left of his fortune) was staked, in turn, upon the success of the community experiment at Harmony, Hampshire. During the exuberant years when its outcome appeared favourable, his fame once again rocketed; when the gamble was lost in 1845 , it came down with equal speed, leaving Owen in his final years far more an object of curiosity than devotion or even antipathy. In the realm of government Owen's influence was deeply felt during this period, and it was the scheme of "elective paternal government" with which his name was often prominently associated among many of his own followers. This scheme occasioned an enormous amount of disunity, and split the socialist movement at all of its levels, in the leadership of the central board, at the annual congresses, in the branch organisations, and finally, doubtless hastening its demise, in the Harmony community. This dissension, and the impetus it gave to a more traditional brand of democracy in the socialist movement, is too complex to be detailed here. Of more immediate relevance, rather, is an analysis of what Owen himself was trying to do, and how it fitted into his conception of the best ultimate form of human government.

As its name implies, the "elective paternal system" was designated by Owen as the mode of transition between the old ways of governing the world, and the future system of paternal social organisation. To some extent even the concept of a transitional form was anomalous to Owen. The consistency of the old immoral and new moral worlds varied as much as oil and water; there could be "no attempt to unite the two states of society. [...] they can never amalgamate in any proportion, and it will, therefore, be useless to draw inferences on the new system from any thing we see

66 Northern Star, 18 March 1843, p. 7. 
around us." 67 This view, however, was clearly a defence against present failings. Owen had always envisioned some form of practical accommodation with the needs of the present, and in fact it was this understanding which underlay his early (and continuing) plans for at least partial control by the capital investors in each community, rather than any sort of class preference for capitalists per se. The purpose of the intermediate or preparatory government, however, was also educational, as opposed to the mainly "watchful" government which would follow later, where education would be integrated more fully into all stages of the social system. Only "the individuals the most experienced and successful in governing" were capable of undertaking what Owen emphasised was "the most difficult task that man will ever have to perform; it is the step of difficulty and danger." 68

Having considered several modes of effecting the transition from the old to the new world, Owen in late 1834 settled upon the union of the most rational members of society as his personal choice, and presented to his followers a clear plan of what the government of the new association would look like. It was to be "paternal, and one of unity", and would consist of a Governor, called "The Social Father of the New Moral World" (to encourage the growth of a familial atmosphere), a Senior Council of twelve, all aged 35 or more, a Junior Council of twelve, aged 25-35, and an executive of six, four chosen from the senior members by themselves, and two from the junior members. The "Social Father" was to be appointed by the unanimous choice of the two councils, the executive, by the unanimous concurrence of both the "Father" and both councils. Members of the association would be graded into three classes, passing into each higher class after six months' probation in the previous one. Each class annually was to vote on the continuance of each member in that class. Should any fail to receive a majority, they would return to the lower class. Legislation had to be unanimously proposed by the "Father" and executive to the Senior Council, and unanimously recommended by them to the Junior Council. Any amendments at all stages had to be unanimously proposed upwards, and then unanimously returned downwards. Finally, when complete agreement was reached by the "Father", executive and councils, each class separately was to consider the proposed regulation. If a majority of the classes approved, the measure would become law: if not, it should "be suspended until such assent shall be obtained through conviction

is Owen, The Marriage System, p. 3.

68 Robert Owen's Weekly Letters to the Human Race, XIII (1850). p. 127: Owen. The Book of the New Moral World. op. cit.. II. pp. 42-43; VI, p. 61 
produced by sound argument and matured judgment". Enactments could additionally be prevented, however, if any member of any class could show, in a public assembly of the association, that the measure proposed was "not in strict accordance with the laws of nature". ${ }^{69}$

This was the form of government which basically prevailed during the first five years of the history of the Rational Society, as the amalgamated socialist organisations came later to be called. ${ }^{70}$ After a slow start, the branches began to expand quickly. There were only three by mid 1837; nine months later there were twenty. By July 1838 thirty-five were recorded, and in October, almost fifty. ${ }^{71}$ Contributions and levies began to arrive in small but steady increments, and with them the reality of a new community began slowly to take shape. In mid 1835 the New Moral World, the Society's journal, reprinted the British and Foreign Philanthropic Society scheme for the government of communities by those who furnished the capital. At the second annual congress of the AACAN, in 1837, the branch delegates agreed in principle that, for at least the first two or three years, such government should be by one person. At the 1840 congress this system was clarified. The governor of Harmony was to be elected by two-thirds of the branch delegates sitting in congress. This was entirely in accordance with Owen's original principle; it merely happened that, on the joint-stock principle, there were some hundreds of capitalists involved as members of the local branches. Only when this capital was repaid, explained the editor of the New Moral World (George Alexander Fleming) in early 1841 , could the actual members of the community be entitled to elect their own managers in every department. ${ }^{72}$

For the first five years of the Society's history, then, the joint-stock principle theoretically operated in a relatively democratic form, with the branches providing both funds and delegates, and in theory exercising control over the president and central board of the Society at the annual congresses. At the 1841 congress, however, Owen introduced and brought into practice a new system of government for both the central organisation and the branches, termed the "elective paternal system". Just prior to the

69 New Moral World, 22 November 1834, pp. 27-28; Jones, The Life, Times, and Labours of Robert Owen, op. cit., p. 314. The full constitution of the AACAN is given in the New Moral World, 7 March 1835, pp. 145-47.

${ }^{70}$ This was a shortened version of the Universal Community Society of Rational Religionists, the branch and financial associate of the AACAN. The two organisations merged in late 1839. See the AACAN Minute Book of the Central Board. Internationaal Instituut voor Sociale Geschiedenis, f. 428 (24 April 1839).

71 New Moral World, 10 March 1838, p. 153; 21 July, p. 309; 27 October, p. 1.

72 Ibid., 1 August 1835.p. 317: 10 June 1837, pp. 247-48; 18 July 1840, p. 43; 3 April 1841 . p. 211. 
congress he had lectured at the Egyptian Hall, Piccadilly, on his new proposals, arguing that

Socialism, in its present state of management among the working classes, must remain in its infancy. The democratic principle is not applicable to the forming and bringing into practice a new discovery, much less entirely new system. [.. .] The Elective Paternal System is alone calculated to carry out any new and complicated system successfully through the transition-state. To devise and execute any great object new to the society, it is necessary to be directed by an elected paternal head, who shall appoint his own officers. $^{73}$

In order to avoid the experience of "divided councils, arising from the democratic principle of governing their proceedings", therefore, each branch was to choose one person as its "father", someone who possessed "the greatest number of the qualities requisite for so important a situation", and allow him to choose his own committee or board. The central government would operate in the same way, with the president choosing his own officers rather than, as previously, having them elected by the congress. Owen also demanded that he be appointed governor of Harmony, with full power over its finances. Not for the last time, he resigned as president of the central board in order to assist in persuading the congress to accept his reforms. ${ }^{74}$

There seems to be little doubt that the financial condition of the Society had much to do with Owen's 1841 decision concerning the best mode of immediate government. For the previous two years, Fleming noted several months after the congress, the poverty of the classes to whom the Society had appealed had left it in a stationary economic condition. In proportion as Owen's new principles for internal regulation were adopted, he added, this situation would improve. Indeed, this was the case for a short time. Several wealthy backers joined the central board on the condition that Owen retained exclusive control over the affairs of the Society, with the most immediate result being the erection of the great hall on the Harmony estate. ${ }^{75}$ To some extent, as well, the "elective paternal system" merely brought the government of the Society in line with Owen's previous experience and inclination. In the Equitable Labour Exchange, and as Grand Master of the GNCTU, Owen had been an elected leader with the right of choosing his own executive. On paper, at least, there was nothing about the

73 R. Owen, An Address to the Socialists on the Present Position of the Rational System of Society (London, 1841), pp. 11-13.

74 New Moral World, 6 June 1841, pp. 348, 353-55.

75 Ibid., 3 July, pp. 1-2; 13 August 1842, p. 52; The Union, 1 December, p. 366. 
system which ought to have agitated too unduly the political sensibilities of those who called themselves democrats. In fact, as the New Moral World pointed out in an address to American socialists shortly after the 1841 congress, the system was the same as that of the United States, where an elected president chose the vast majority of his chief executive officers. ${ }^{76}$

But insofar as "harmony" and "unity" were the chief aims of the new system of government, there is no doubt that Owen's opponents were correct in their suspicion that his mode of government was intended to diminish the process of discussion and voting on all important issues at every level of the organisation, and to increase the powers of a select group of individuals in order to make possible the progress of maximum expenditure on the community that Owen deemed necessary to the success of the experiment. The purpose of the paternal form, as the central board expressed it in 1844, was "to supersede the continual changes and frequent division in council which occurred under the old form of government", and to replace it with the feelings of kindness, charity and mutual good will which formed the behavioural core of Owen's "new religion". ${ }^{77}$ The key word associated with the new form of government was "unity". Democratic executives did not admit "of unity of principle, feeling, or action", resulting in a lack of decisiveness and vigorous execution. The new system of government, however, combined the best parts of the aristocratic and democratic principles, with the result that "as soon as the members acquire a knowledge of the principles and their right application to practice, all anger, ill will, and division among them, must cease; the factions of the old world will die their natural death; a new mode of speaking to, and of, each other, will naturally and necessarily arise, and harmony and good feeling will be evident in the countenance, manner, and conduct, of all."78

There was, nonetheless, considerable resistance to both the proposed form of government in the branches (where on the whole it was rejected) and to Owen's personal policies with respect to the Harmony community. The combination of "a strong democratic controul with an unobstructed executive power", as William Galpin described it, still did give the recalcitrant branches the power to reject Owen's proposals; indeed he had never tried to deny them this ability, asking primarily only that they wholly supported those individuals they had elected to manage their affairs. But Owen refused to lend his personal support to decisions which opposed his

\footnotetext{
${ }_{76}$ New Moral World, 19 June 1841, p. 380.

77 Rational Society, Minute Book of Directors, No 2, 18 October 1844, Internationaal Instituut voor Sociale Geschiedenis.

${ }^{78}$ New Moral World, 18 December 1841, pp. 193-94.
} 
own wishes, and in the two years from mid 1842 to May 1844 he repeatedly resigned from various positions in the socialist leadership when his motions were defeated, and then rejoined when, amidst the growing gloom which accompanied signs of the imminent crash of the Harmony community, the organisation turned to him as the last hope for the salvation of the experiment. ${ }^{79}$

During the final five years of central Owenite organisation, the "elective paternal system" often tended to serve as a symbol, on the one hand, for everything that the advocates of direct democracy and increased workingclass participation found wrong with the central leadership, and, on the other, for the voice of reason, experience and resolution amongst those who sought to avoid the seeming chaos of collective decision-making. As Galpin remarked in 1843, Owen's unity form of government had been and was being "charged with an immense amount of things to which it had no reference whatsoever". ${ }^{80}$ To at least some of the radicals it certainly represented Owen's other three major policy propositions of 1841 , in which the "transition colonies" were to be composed of four classes, hired labourers earning £25-39 annually, candidates for membership (mechanics and artisans) earning an average of $£ 65$ each, full members, and independent families or individuals. The proposed government was to be by a president elected by all members of the third class over 21 years of age. This plan, complained G. J. Holyoake and M. Q. Ryall, was different "from its predecessors in one particular, for it no longer provides that the great political principle of the society should be carried out, viz. equality of age and condition".81 Yet as we have seen, Owen's 1841 plan in fact differed little from that of twenty years earlier, and both schemes represented an attempt to attract the middle and upper classes as investors and community members. Owen did originally plan on having eight types of apartments at Harmony, but it would seem that the most extensive type of division which finally marked community life was a separation into three age groups, which does not appear to have been a source of contention. ${ }^{82}$

Less immediate to the daily concerns of the Society and community, but far more momentous to many of those who disagreed with him, was Owen's attitude towards the Charter and its supporters. This is not the

\footnotetext{
79 Ibid., 9 April 1842, pp. 322, 324; 3 June 1843, p. 406.

80 Ibid.

81 Owen, A Development of the Principles, op. cit., pp. 40-41; The Movement, AntiPersecution Gazette, and Register of Progress, No 19 (1844), p. 148.

82 New Moral World, 18 July 1840, pp. 36-37; Northern Star, 15 April 1843, p. 7.
} 
place for an evaluation of the historical and intellectual connections between the Chartist and socialist movements. ${ }^{83}$ All that it is important to show here is that, while Owen's general view of the Charter's aims accords with his other pronouncements on parliamentary reform, there is at least some evidence that he embraced a more catholic approach to the Chartist struggle, and publicly supported it for a time.

It is necessary to emphasise in this context, moreover, that both during and before the Chartist agitation Owen had presented reform proposals to Parliament which went far beyond merely seeking financial aid for his community plans. Owen's support for the abolition of child labour and passage of the ten-hours bill is well-known, but his reform plans, often published during election years (he offered himself as a Parliamentary candidate approximately ten times) have usually been ignored. Much of this programme remained essentially the same during most of his public career. In 1832, as we have seen, it included seven points: a graduated property tax equal to the national expenditure, the abolition of all other taxes, free trade, national education and employment for those who desired them, and liberty of speech, writing and religion. The 1834 "Charter of the Rights of Humanity" totalled seventeen points, including the abolition of war and of the domination of one religion. In the 1842 "Charter of the Rational System", Owen added the provision of a national form of money (i.e., based upon a labour, not a gold standard), plus marriage by registrar, with divorce freely accessible. The 1843 "Preliminary Charter of the Rational System" consisted of twelve points, of which the most significant addition was the proposal that the exchangeable value of all wealth was "to be decided by properly qualified officers, who will have no private interest to bias their judgment". 84

Hence in the first decade of Chartism, Owen never included any of the points of the Charter in his own proposals. This was still the case - despite Rothstein's contention - in the 1847 election, where Owen, having declined to go to the poll at Marylebone, nonetheless received (much to the amusement of the other candidates' supporters) one vote out of 15,050 cast (though Holyoake claimed that upon the basis of a show of hands Owen could have won the election). It seems somewhat difficult to explain, then, the fact that on 15 March 1848, after the revolution had begun in Paris,

83 See E. Yeo, "Robert Owen and Radical Culture", in: Robert Owen: Prophet of the Poor, op. cit., pp. 84-114.

84 Robert Owen's Reply to the Question, op. cit., p. 12; Crisis, 1 March 1834, p. 219; New Moral World, 23 April 1842, p. 337; Preliminary Charter of the Rational System (London, 1843) (broadside). 
and as it appeared in Germany, Owen published a ten-point plan which included "Representation co-extensive with taxation, the voters to be protected by the ballot, and the representatives to be paid for their services". ${ }^{85}$ Several months later, too, he recommended a constitutional convention chosen by universal suffrage from all European peoples, "defective as this suffrage would be in many cases". ${ }^{86}$ Clearly, however, Owen saw such changes as the only means of preventing a revolution in Britain. The new French revolution, he wrote, had "like electric magic, shivered this system to atoms; it no longer exists in the minds of those who understand political movements, and who, from existing causes, can foresee future events." $87 \mathrm{He}$ journied to Paris himself, dispensing pamphlets and advice to all who would listen, and writing back that "No nation or people ever had so promising an opportunity to establish a good government and a superior society as the French people at this crisis in their history." 88 And when the cause was lost, Owen shared in the disappointment of many more insurrectionary observers.

Had it not been for the Revolution of the three days of February in Paris, the the old falsehoods and evils of society might have tormented the human race with injustice and cruelty for many years; but, fortunately for the world, Nature forced on that Revolution, which had become necessary by the crimes and oppressions of the old society, to which the industrious producers of all wealth could no longer submit. And of all the murders, bloodshed, and violence following, old society is the cause; the re-action, as it is called, is to uphold the robbery, injustice, and murderous cruelty of this system of falsehood and deception. ${ }^{89}$

This was probably no great consolation to the French, however, and it seems equally doubtful that many of the Chartist leaders were overwhelmed by Owen's change of heart in 1848, when he had little money, virtually no organisation and few followers, when they recalled his refusal

${ }^{85}$ Th. Rothstein, From Chartism to Labourism (London, 1929), p. 8; University of London Manuscript 578, f. 173; Reasoner, III (1847), p. 446; R. Owen, Practical Measures Required to Prevent Greater Political Changes in Great Britain and Ireland (London, 1848) (broadside), also printed in the Northern Star, 25 March 1848. p. 3.

86 Spirit of the Age, 21 October 1848, p. 203; Northern Star, 21 October, p. 1.

87 R. Owen, Socialism Misrepresented and Truly Represented (London, 1848), p. 16.

${ }^{88}$ Owen to Thomas Allsop, 14 April 1848, British Library, Additional Manuscripts 46344. ff. 57-58.

${ }^{89}$ Spirit of the Age, 4 November 1848, p. 235. See also R. Owen, Dialogue entre La France, le Monde, et Robert Owen (Paris, 1848); id., Dialogue entre les Membres de la Commission Exécutive, les Ambassadeurs d'Angleterre, de Russie, d'Autriche, de Prusse, de Hollande, des Etats-Unis, et Robert Owen (Paris, 1848). On this episode in Owen's life, see C. Tsuzuki, "Robert Owen and Revolutionary Politics", in: Robert Owen: Prophet of the Poor, pp. 13-38. 
to support the six points in the early 1840 's, when his power and influence had been comparatively great. In his "Address to the Chartists" in early 1842 , for example, Owen accused those who sought the six points of vastly overrating the effects which would result from their passage. None of the Chartist leaders had "yet exhibited a knowledge of the cause of the evils now so heavily pres[s]ing on society, or of the remedies for those evils". The Charter, moreover, would "make all petty politicians", with each requiring that "his individual, crude, and undigested measures should be attended to as those of any other independent elector or member of parliament". The social benefits of universal suffrage were surely evident in the USA, which possessed "in great abundance, all the materials, power, and means of prosperity and happiness for $10,20,30$, or 40 times their present population; and yet, with all the points of the Charter secured, they are actually suffering innumerable evils with a population not exceeding eighteen or twenty millions. In fact, the territory of the United States is more than sufficient to support in high comfort all the present inhabitants of the world." 90

It is nonetheless possible that Owen did at least attempt to effect some form of alliance with the Chartists. Writing in 1850, John Finch, a Liverpool merchant and follower of Owen since the mid 1820's, claimed that Owen visited the principal Chartist leader, Feargus O'Connor, while the latter was imprisoned at York Castle in 1841, and that "union was at that time effected, but unfortunately it was never carried out in practice". ${ }^{91}$ The programme jointly agreed upon was the same as that in Owen's 1832 address, with the addition of support for the points of the Charter. Since there was nothing particularly socialistic in these points, O'Connor certainly had no ideological reason to forsake such an alliance. Though he was definitely opposed to Owen's views on community of property, by 1845 O'Connor was so concerned with settlement on the land that he was willing to begin on the "individual system", "leaving the people to co-operate ultimately, if they saw fit". The failure of the alliance, rather, had probably more to do with Owen, who as we have seen decided upon a somewhat different political strategy a few months later in $1841 .^{92}$

Owen's later position on the Charter is only moderately more ambiguous than his earlier views. Nominated to the new executive committee of the National Charter Association in 1850, Owen refused, complaining that "Chartism knows not how to well-employ, to well-educate, or to well-

90 New Moral World, 30 April 1842, p. 349.

91 Weekly Tribune, 16 March 1850 , p. 3.

92 Northern Star, 26 April 1845, p. 6. 
govern any society." ${ }^{, 93}$ In 1857 he was reported as receiving great applause when he supported the Charter at a meeting of the National Charter Association. In 1858, the final year of his life, he recommended that the six points should be passed "in a liberal installment" by "a liberal, good, practical reform of Parliament" which would give a vote "to all competent to make a rational use of it". ${ }^{94}$ By then, however, more than ever, Owen's political opinions were of little consequence to most of those around him. The Charter agitation had arisen without his assistance, and equally well passed away in spite of it.

\section{Paternalism and federalism: The ultimate character of the state}

The previous section discussed two types of transitional government. The first, or "elective paternal" form, was designed by Owen to combine aspects of existing representative governments with features of the future, exclusively paternal form. As Owen explained shortly before departing for America in 1844, leaving the shambles of Harmony behind him, there was no "more determined enemy to inequality than himself. It was the great object of his life to destroy it". He denied that he was "an ingrained, thorough aristocrat". ${ }^{55}$ But equality in education, training and social position were first required, and it was the purpose of his own transitional form of government to provide these. Secondly, there was the question of the transitional form of national government, and here, in his strictures against the Chartists, and elsewhere throughout most of his career, Owen adhered fairly consistently to the view that "The existing machinery of the established governments in all countries will be found to be the best to assist to bring about this change, and conduct it, through its transitionstate, into all the advantages of the full new or millennial existence." 96

In this section a much closer analysis of the "paternal" character of Owen's idea of the state will be made, with a view to situating Owen more exactly among those of his contemporaries who also used the rhetoric and concepts of paternalism, and hence specifying the peculiarities of his own thought more clearly. Secondly, Owen's conception of a federated state and international structure will be examined, both as a means of further explaining the total shape of his political ideas, and in order to contradis-

93 Robert Owen's Journal, 28 December 1850, p. 65.

94 "Reminiscences of Thomas Dunning", in: Testaments of Radicalism: Memoirs of Working Class Politicians, 1790-1850, ed. by D. Vincent (London, 1977), p. 223; Robert Owen's Millennial Gazette, 1 May 1850, pp. 13, 40.

95 A Full Account of the Farewell Festival, op. cit., pp. 7-8.

96 R. Owen, Lectures on the Rational System of Society (London, 1841), p. 164. 
tinguish the centralising and decentralising emphases in his social theory as a whole.

That "paternalist" ideas were an integral part of both the social theory and intercourse of early-nineteenth-century Britain has of course long been recognised. The analogy between the state and family is as old as political thought itself, and it was really only with the popularisation of Lockean contractualism in the late seventeenth and early eighteenth centuries that an alternative explanation became widely available. In the paternalist or patriarchal account, the state and society were held to be essentially identical, with the origins of both lying in some original form of primitive familial association. Obedience to the state was justified on the grounds that political authority had originally belonged to the father. Hostile to this account was the conventionalist view which is most often associated with Locke, where the state and society are held to be entirely separate entities, with the authority vested in the former being the result of a mutual contract among the members of the society. Political authority here is held to be artificial and voluntary, rather than naturalistic and inherently bound up with an original hierarchical principle at the root of all social structure. ${ }^{97}$

While such views may have lost of their popularity in the aftermath of 1688 , one author, at least, has lately found them alive and well amidst the social fabric of early-Victorian England. The general "model" of paternalism developed by David Roberts, however, would seem to be of only dubious utility to our purposes here, even though Roberts does assert that Owen ran his communities "along strictly paternalist lines". The paternalist world-view, according to Roberts, was authoritarian, hierarchic, organic and pluralistic. The typical paternalist believed "in capital punishment, whipping, severe game laws, summary justice for delinquents, strict laws defining the duties of servants, and the imprisonment of seditious writers". ${ }^{98}$ Certainly none of this is true of Owen. Closer to the latter's views, however, was the alleged paternalist emphasis upon the maintenance of small communities, where governors and governed were mutually acquainted, and hence maintained reciprocal bonds of authority and deference, although of course Owen denied that property ought to be the principal basis of such authority. Even if the phrase "paternal government" was a popular one in Parliament and the press during the 1840's, this in Roberts's view actually meant little more than a call for the protection of

97 G. J. Schochet, Patriarchalism in Political Thought (Oxford, 1979), pp. 10-14, 20-22, 54-58, 271-75.

98 Ibid., p. 273; D. Roberts, Paternalism in Early Victorian England (London, 1979), pp. $273,2-3,270-71$ 
the poor, weak, helpless and infirm, often coupled (in Sewell, Seeley, Coleridge and Oastler, for example) with a desire for both a strong monarchy and a decentralised government. The latter apparent contradiction does provide some means of situating Owen's political thought, as we will see shortly. ${ }^{99}$

It is more difficult to place Owen within Roberts's general use of "paternalism", however, because the concept itself is extended so widely as to lose much of its explanatory capacity. It is thus perhaps more fruitful to compare Owen's views more directly with those of some of his contemporaries, especially those with whom he was himself acquainted, or whose views were doubtless familiar to him. What most centrally distinguishes Owen's paternalism from that of virtually all his contemporaries, of course, was the grounding of the former in the aetatic or gerontocratic principle. This, for Owen, was the only just and natural principle of hierarchy, and he frequently condemned those who sought to introduce other less rational principles in its place. Hence when the Saint-Simonian missionaries Fontana and Prati visited England to preach their doctrines in 1834, Owen accused their founder of having been totally ignorant of human nature, specifically pointing to Saint-Simon's ideas of hierarchy and reward according to capacity. ${ }^{100}$ It should be recalled, too, that other like-minded socialists did accept such principles when Owen did not. In John Goodwyn Barmby's communitorium all power and authority were vested "in the pater or father". In Barmby's ultimate plan for world government, both men and women would vote, but all women would be ineligible for the position of Communarch, or ruler of the earth, because "every thing is subordinated to the prime male principle of nature". ${ }^{101}$ Other less wellknown writers, such as John Thimbleby, also seem to have accepted the principle of male superiority. ${ }^{102}$

Far more important, given its extremely widespread dissemination and acceptance, was Owen's rejection of any ontological argument based upon the new discipline of phrenology. A great many of Owen's friends and followers did embrace the science of analysing bumps on the skull, with its strong element of physical determinism. E. T. Craig used it to analyse applicants for the Ralahine community (evidently neglecting the owner of the land, who lost his estate gambling), and the Coventry ribbon-manufacturer and Owenite Charles Bray obligingly shaved the head of the

99 Ibid., pp. 187-89, 202-03.

100 Crisis, 15 February 1834, p. 207.

101 The Educational Circular and Communist Apostle, December 1841, p. II; May 1842, p. 44.

102 J. Thimbleby, Monadelphia (London, 1832), p. 40. 
young George Eliot in order to reveal her mental make-up, and himself believed, as he expressed it to George Combe, the great populariser of phrenology, that "the best men must be educated first". ${ }^{103}$ But Owen would have virtually nothing to do with this. From the time, in 1824 , when George Combe wrote to Owen that "your system appears to me to originate in the peculiarities of your own cerebral development", Owen was consistently opposed to ontological deductions from this new science. ${ }^{104}$ In an 1835 "Address to Phrenologists" Owen criticised Combe by way of emphasising "the all-surmounting power of education", and elsewhere he accused the phrenologists of "leading the public much astray" by reducing, for example, the whole question of private property to the mere operations of the organ of acquisitiveness, and generally assuming that the present condition of man was "his natural and fixed state". ${ }^{105}$

Nor did Owen's paternalist principles ever convert into a plan for a temporary despotism of the usual variety, political dictatorship. In the mid 1830 's Owen was certainly given the opportunity to consider such a policy via his association with James B. Bernard, an eccentric Tory and fellow of King's College, Cambridge, who sought to effect an alliance between farmers, the aristocracy and working-class radicals in order to destroy the manufacturing interest, and restore (with the addition of certain novelties, like an elective monarchy) the preponderance of the landed gentry. For about a year Owen was associated with, and paid quite close attention to, Bernard, but although he shared the latter's views on the need for the predominant influence of one individual during the transition period, Owen ultimately departed from Bernard on the issue of the necessity for violent revolution, which in turn was closely linked to the form such leadership would take. J. E. Smith, Owen's editor at the Crisis, did, how-

${ }_{103}$ E. T. Craig, A Remedy for the Pacification of Ireland (Dublin. 1870), p. 12: see C. Bray, Phases of Opinion and Experience During a Long Life (London, 1879), pp. 73-77: Bray to Combe, National Library of Scotland, Manuscript 7305, f. 65.

104 Combe to Owen, 28 January 1824, National Library of Scotland, Manuscript 7382, f. 368. See G. Combe, "Phrenological Analysis of Mr. Owen's New Views of Society", in: Phrenological Journal, I (1823-24), pp. 218-37. The commentary below the text of this article by "a zealous and able advocate of the new views" is identified as that of Abram Combe, George Combe's brother and one of the founders of the Orbiston community, in National Library of Scotland, Manuscript 7383, f. 14. On Owen's relations with the Combe circle, see A. C. Grant, "George Combe and His Circle: with Particular Reference to His Relations with the United States of America" (Ph.D. thesis, Edinburgh University, 1960), pp. 55-67.

105 New Moral World, 3 April 1835, pp. 180-83; 18 April, p. 200; R. Owen. A Dialogue in Three Parts Between the Founder of the Association of All Classes of All Nations and a Stranger (London, 1838), p. 13. 
ever, alter his views to accord more closely with Bernard's, but Owen appears not even to have flirted with such an idea. ${ }^{106}$

It has also been argued, both by George Jacob Holyoake (who knew Owen) and some later commentators, that Owen's paternal concerns were so much with social condition and so little with personal liberty that he "saw no objection to slavery, when beneficially controlled". ${ }^{107}$ This impolite fiction originated (it would appear) in Owen's remark, returning from a visit to the West Indies, that the slaves there were generally more comfortable than were Irish or English day-labourers, which, even in 1829. was probably often true. ${ }^{108}$ But this comparison, in any case, was standard in the rhetoric of factory reformers like Oastler and Fielden, as well as Chartists like O'Connor, who, following upon the successes of Wilberforce, Clarkson and others in securing the abolition of slavery in the British Empire, found the idea of "white slavery" to be among the most powerful modes of symbolising the increasing degradation of free-born British operatives. Owen, rather, believed that "tyrants and slaves are never rational", and that any future society must be devoid of "slavery and servitude, that no inferior impressions may be made upon any of our faculties". ${ }^{109}$ Closer to the end of his life, too, he cited the abandonment of slavery as a condition of America's becoming the country where the transition to the future could take place. ${ }^{110}$

If we examine, furthermore, the ultimate social and political ideals of men like Michael Sadler and Richard Oastler, with whom Owen has been and conceivably might be compared, far greater differences emerge than similarities. Like Owen, both Sadler and Oastler were implacably hostile to Malthusian political economy and its legislative offspring, and to the crude application of laissez-faire and the social dislocation and pauperisation which accompanied the widespread introduction of machinery. Sadler's biographer termed his system "paternal" by contrast with the prevailing "selfish" system. ${ }^{111}$ Oastler, too, held that England needed a "paternal government", and believed in "the social state", but what this meant was a properly maintained hierarchy of rank and station based upon "the Altar,

106 See G. Claeys, "A Tory Utopian Revolutionary at Cambridge: The Political Ideas and Schemes of James B. Bernard, 1834-39", in: The Historical Journal (forthcoming, 1982).

107 G. J. Holyoake, Life of Joseph Rayner Stephens (London, 1881), p. 188; see Sargant, Robert Owen, op. cit., p. 267, and Harvey, Robert Owen, op. cit., p. 137.

108 Robert Owen's Opening Speech, p. 189.

109 Owen, The Book of the New Moral World, I, pp. 65, 63.

110 Robert Owen's Journal. 8 November 1851, pp. 14-15.

111 Memoirs of the Life and Writings of Michael Thomas Sadler (London, 1842), pp. 33, $67-68,379,447$. 
the Throne, and the Cottage". Owen could never have commented, as Oastler did:

Do I then say that there should be no grades in society, that there are not to be servants and master? No! But I do say that servitude and labour ought not to be oppressive. I know from my own experience - for I am but a servant - that I have as much pleasure in serving my master as my master can have in receiving my services. No master has a right to demand the services of any human being unless the reward of those services will be a comfortable living. And that is, I verily believe, all the working classes want. ${ }^{112}$

This may well have been an accurate description of the desire for "a fair day's wage for a fair day's work", which seems to have been the slogan accepted by large parts of the working classes, but this never affected Owen's ultimate vision, and did not prevent him, during the GNCTU agitation, from telling an audience of operatives that "Were you to become masters, and employ great numbers of men, that circumstance would change your mode of conduct, and unless you now elevate your minds, fairly look your difficulties in the face, and go to the root of the evil, all your exertions will avail nothing. The system of masters and servants must be superseded." 113

With the political ideas of such men, and others like them, Owen did share a profound mistrust of contemporary political radicalism (although they too were involved with it to some extent), and more specifically of the ostensible benefits to the social condition of Britain of the immediate passage of universal suffrage. Owen, too, believed in the necessary existence of a principle of social hierarchy, but this had nothing to do with economic class, hereditary privilege or even, in the end, of virtue. The paternal character of the "educational principle of government" ultimately bears very little relation to the paternalism which was embraced by and is associated with many of Owen's contemporaries. Even the quite specific concept of "elective paternal government", while its final reference point is a paternalist model of the family, has far less to do with any broad ideal of paternalism than it does with Owen's specific preference for an essentially American form of cabinet government as the interim form of rule, as against demands for a greater prevalence of direct democracy. Before

112 The Fleet Papers, 31 July 1841, p. 247; C. Driver, Tory Radical: The Life of Richard Oastler (Oxford, 1946), pp. 130, 203, 427.

113 The Official Gazette of the Trades' Unions, 14 June 1834, p. 14. See R. L. Hill, Toryism and the People, 1832-46 (London, 1929), p. 178, for a discussion of Owen which terms him "the very incarnation of benevolent Toryism applied to industry". 
concluding, then, it is necessary to examine one final aspect of Gwen's political ideas as a means of situating him both within his own time and in the history of socialism as a whole, and that is the relation between the centralising and decentralising tendencies in his conception of the state.

From the last decade of his own life up to the present, Owen has often been assumed to have proposed a voluntarist, peaceful and decentralised theory of socialism, in contrast to both earlier and later systems of centralised state management preceded by either an insurrection or a more class-conscious revolution. Alexander Herzen went so far as to imply that Owen wanted no government at all, and compared Babeuf (unfavourably) as the "surgeon" of history, intending state supervision and organisation of everything, to Owen as the "man-midwife" opposing to force the rule of reason. ${ }^{114}$ Owen would, however, be ill-placed in a history of anarchism. Writing in 1850, he specifically distanced himself from Proudhon, whose ideas were becoming well-known in Britain, and who, in Owen's description, desired "the world to govern itself without a government".

M. Proudhon has discovered that all past and proposed governments, as all have been based on the old error of society, are bad, and unequal to make man and society what both should be for the happiness of our race. And he is right: adopt any form of government based on the old error of the world respecting man and society, and failure and disappointment are sure to ensue. But it does not follow that the population of any country can do without governing arrangements; or that a good government cannot be devised, and beneficially carried into execution. This would be going from one extreme of error to another, and to act on the supposition that a good government cannot be formed for the human race. ${ }^{15}$

There is, however, a large amount of truth in the view that Owen envisioned a world government which was essentially built upon a federal structure with communities as the basic units of self-government. Much of the federalist rhetoric in Owen's writings occurs after 1845, but it is possible to trace his initial acceptance of such concepts to his first community at New Harmony. It was here, in the mid 1820's, that Owen first began to speak of his communities as standing "in the same relation to their respective state governments, that the states now do to the general government". ${ }^{116}$ The germ of such ideas Owen had carried with him at least since 1817; to some extent in any case they were bound to be independently associated with his community plans. Certainly as early as

114 A. Herzen, My Past and Thoughts (3 vols; London, 1968), III, pp. 1236, 1240. Thanks to Christine Lattek for this reference.

115 Robert Owen's Weekly Letters to the Human Race, XI (1850), p. 99.

116 New Harmony Gazette, 23 May 1827, p. 265. 
1821, we find a writer in the first important Owenite periodical, the Economist, referring to a proposed member of such colonies as "a co-operative federalist". ${ }^{117}$

Nonetheless it seems quite likely that Owen derived some of the theoretical inspiration for his federalist ideas from William Maclure, philosopher, educator and inventor, who eventually seceded from the main community at New Harmony in order to govern a smaller colony ("Macluria") on his own. Maclure was fairly convinced that "the smaller the political society, the better every thing is administered for the interest of the many, and that the corruption and mal-administration of all nations, is in exact proportion to the extent of territory and number of beings over whom their rulers domineer". ${ }^{118} \mathrm{His}$ plan, accordingly, was to pay political labour at the same rate as all other forms, and to ensure that every office of power was elective, rotated as often, and delegated as infrequently, as possible. Besides a general social equality which should "force every consumer to be at some time a producer", the only way to reconcile the interests of governors and governed was to divide power as far as possible, "alternating and reciprocating authority, so as to make the governed of this day, month or year, the governors of the following day, month or year". Another possible contributor to Owen's federalist notions was William Thompson, whose Labor Rewarded included a detailed plan (also however involving elections at all levels) for a national government which was essentially federalist in character, though Thompson did recognise certain inadequacies in the American system. ${ }^{119}$

The idea of continual rotation, as we have seen, gave Owen political indigestion, but he did go on to develop the federative theory into a fully-fledged concept of world-government. In one of the first such statements, Owen proposed that the youngest individual who had passed out of the general council of a community might be delegated to the united council of a circle of ten communities, the second-youngest to the council of a hundred communities, and the eldest to the council of a thousand communities. The eldest members of the latter councils would form a council representing the interests of a hundred thousand, a million or more communities. ${ }^{120}$ Certain details were added to this plan at various times, but its shape remained basically unchanged. Especially after Queenwood

Economist, 18 August 1821 , p. 66.

118 W. Maclure, Opinions on Various Subjects (3 vols; New Harmony, 183I-38), I, p. 33.

119 Ibid., p. 83: II. pp. 317, 452; W. Thompson, Labor Rewarded (London, 1827), pp. $121-24$

120 Robert Owen's Opening Speech, pp. 139-40. 
seemed lost, Owen became increasingly persuaded that because conditions in the USA were "by far the most favourable", it ought to be the "Central Power" of the Federative Union, and he even went so far as to design, helpfully, a draft "Provisional Treaty of Federative Union" between Great Britain and the United States. But this was only intended as a means of beginning the process of community-building, for ultimately all national boundaries were to disappear inside of an organisation of state, national and continental federations. ${ }^{121}$

If Owen's federalist plans are, on the whole, both simple and (to some observers) simple-minded, his views on the uses of state power in the period before communities were actually built are perhaps more interesting. Owen's communitarianism can be described in terms of certain moral, political and educational imperatives towards decentralisation. The latter element in some sense, of course, already includes the two former. Rhetorically answering his own question as to why communities could only contain three thousand people, Owen thus responded: "For very many important reasons respecting education, training, occupation, wealth, amusements, and the general enjoyment of life; but especially because by this simple arrangement every one from birth to death will have his physical, intellectual, moral, practical, and spiritual character well formed for him, and will be without difficulty well cared for through life by society." 122

For all his insistence upon the virtues of community life, however, almost every practical proposal Owen made in his career, especially after the final demise of Harmony in 1845, was in fact calculated to increase the power of the state, thus creating a political paradox which was to become far from uncommon in later brands of socialism. From the point, in 1817, when Owen first spoke of "nationalizing" the problem of the poor, to the mid 1850's (when the Times defined "socialism" as "every attempt [...] to invoke the interference of the legislature in those contracts which any one man is compelled to make with another") and down to the present day, the principles of socialism have been identified with a policy of widespread state intervention both in the economy, and to a lesser extent in other spheres of civil society. ${ }^{123}$ In his later years Owen was incurably attached to the idea that the state alone should found co-operative communities, and

121 Manifesto of Robert Owen (Washington, 1844), p. 5; Communitist, 12 September 1845, p. 21: Robert Owen's Journal, 8 November 1851, p. 14; 6 March 1852, p. 149: Spirit of the Age, 7 October 1848, p. 171: R. Owen, Reasons for Each Law Proposed to be Introduced First into the State of New York (Washington, 1846), p. 21.

122 R. Owen, The Millennium in Practice (London, 1855), p. 20.

123 Id., "A Catechism of the New Society", in A New View of Society and Other Writings, p. 184; The Times, 7 July 1853, quoted in Roberts, Paternalism, op. cit., p. 203. 
always seemed to feel throughout his career that one more argument voiced in the proper ear at an opportune moment would be sufficient to set the wheels of government in motion on his behalf. When the simple, rational truth was made perfectly clear to one and all (hence Owen's fondness for repetition, which seems to have been based on the principle that, when talking to foreigners, shouting raises the chances of their understanding our language), existing governments would see the light and simply abolish themselves.

Owen did of course suffer a lifetime of disappointments as a result. In 1851, recalling the first of these, the mutilation of his proposed childhood-employment bill at the hands of a Parliamentary committee, he reflected that "I saw so much sacrifice of truth and correct feeling, for supposed personal or class advantages, that I became thoroughly cured of my veneration and high opinion of our legislators". ${ }^{124}$ There is probably less self-delusion in this than might be supposed. Alexander Herzen once asked Owen why he continued to petition autocrats like Nicholas of Russia. Owen's response was revealing: "While a man is alive one must not despair of him. There are so many kinds of happening that may lay open the soul. Well, and if my letter doesn't work and he throws it away, where's the harm? I shall have done what I could. It is not his fault that his upbringing and the environment in which he lives have made him incapable of understanding the truth. In such a case, one must not be angry but feel pity." 125

But to some extent, and especially after 1845 , Owen had to call upon the state to found socialism, regardless of the extent of his faith in its leaders. Private philanthropy had failed him miserably (and in any case he kept raising the amount required to really make a success of things), class action by labourers and artisans was out of the question after 1835 (and had never been his preference anyway); there were really few other alternatives on offer. This had other consequences of greater theoretical interest as well, for in effect it drastically increased the necessary scope and responsibilities of the state. The more Owen failed, the more he asked from government, and by 1846 he was even denying what up until a year earlier he had been practising, that individuals could buy the land upon which to begin communities, "because that would be to retain all the present evils of private ownership of land, and nothing could be gained to forward the object sought for - that is, to make the land the property of the population, for its use, without alienation, from generation to generation. To effect this

124 Robert Owen's Journal, 1 February 1851, p. 108.

125 Herzen, My Past and Thoughts, op. cit., III, pp. 1207-08. 
object, the land must be purchased by the Governments, in the first instance". ${ }^{126}$ Six years later Owen emphasised that governments should not only purchase the land, but also build, furnish and stock the individual townships. ${ }^{127}$

Yet to some extent the problem became national much earlier, when Owen defined the solution as requiring momentous exertions, and if the relief of the parish poor was a problem requiring national resolution, the salvation of the country as a whole could scarcely be less so. Placing the whole of the solution in the hands of the state in this sense merely represented the working out of a logic which had been put forward much earlier. Certainly from at least 1817 onward Owen believed that governments had, and ought to have, full responsibility for all of the "circumstances" within their sphere of influence, and having ascertained the best use of these circumstances, had the duty, as he later put it, "to form the whole social arrangements in such a manner as to induce, or morally compel, all men to act in conformity with this knowledge". ${ }^{128}$ The need for a rational interim education hence provides a centralising, state-oriented tendency of its own: "The creation of the circumstances to well educate man, is a national work, to be directed by national wisdom, and executed by national capital", as much as any other reason "in order that the education for all should be the most useful and the best that national means can give, and that there should be harmony throughout the nation, and with other nations". 129

It was also suggested above that there was another centralising tendency in Owen's thought which was economic, but which was quite separate from any consideration of the simple magnitude of the problem. Owen's opposition of laissez-faire came not only from a consciousness of what he took to be its immediately harmful effects, but also, from the managerial and administrative point of view, from a simple belief in its inefficiency. Laissez-faire, he wrote to Brougham in 1855 , might be "very well for ignorant governments, who by their active measures would injure their subjects, but the worst possible advice for those who have to govern the improving populations of Europe and America. For the time has now arrived, especially in Great Britain, filled as it now is with scientific power of production, when individuals without the aid of government can do

126 Letter from Mr. Robert Owen to the President and Members of the New York State Convention, op. cit., p. 27.

127 Robert Owen's Journal, 24 January 1852, pp. 103-04.

128 Owen, The Book of the New Moral World, I, p. 52.

129 Ibid., II, pp. 32-33. 
nothing effectual to relieve the country from its daily accumulating difficulties." ${ }^{130}$ Equally important in an economic sense, however, was

the waste of time and loss and deterioration of quantity and quality, arising from dividing and subdividing, and sending wealth first to one place, then to another, through many successive changes, [which] adds to the labour of the producers one-third, if not one-half, more than would be required for well-arranged production. Nine-tenths of the cost and labour now required to distribute the inefficient and inferior wealth created under the present wretched system of competitive individualism, might be most beneficially saved, under a principle of governing which rendered it necessary that the governors should understand the true theory and practice of governing for the mutual benefit of the governors and governed. ${ }^{131}$

Owen does not seem to have felt that, once the communitarian system was widespread, too much of an extra-community administrative apparatus would be required; at least he never really planned for such an eventuality. Other writers in this period did evolve a fully centralised plan of state economic management, but Owen never carried his ideas so far. On the whole his mind was too imbued with the virtues of community ever to become fully caught up in the logic of a national and international economic system. In this aspect of his theory, rather, the logic of the paternal state tended to give way before that of the federal state, and not the reverse, even if in his writings Owen did not manifest that vehement opposition to the principle of centralisation which was characteristic of men like Oastler. ${ }^{132}$

\section{Conclusion}

Categorising the politics of an individual as complex as Owen, this article has argued, is far more difficult than is usually assumed. A fair number of Owen's contemporaries found him to be a man possessed by one fixed idea, and even become mad through his rigid adherence to the doctrine of circumstances, and his perpetually disappointed striving for the millennial world of rational human beings. That Owen was often far from being a realist in the usual sense of the word is a judgment most of his biographers would doubtless regard as an understatement. The reason for studying his political ideas does not therefore lie in the depth of his perceptions of contemporary political institutions, mores or actors. Most of these Owen often saw "through a glass darkly", to use his own (Biblical) description

130 Owen to Brougham, 1855, Owen Collection, No 2533, Holyoake House, Manchester.

131 Owen, The Book of the New Moral World, II, p. 44.

132 For Oastler's opposition to centralisation see, e.g., The Fleet Papers, 17 April 1841, p. 122. 
of the quality of others' vision. On occasion Owen demonstrated certain insights into the working of any political process, using his authority to get his own way, or varying the emphasis of his plans according to his audiences' inclinations. But equally often he failed to do so, and he was not, in this sense, a political animal of any of the more common species.

But Owen was nothing if not a man of principle, and his principles ultimately impinged much further into a recognisable landscape of political ideology than most of his interpreters have yet suggested, or than any have cared to detail. Owen lived through an age (particularly in the 1830's and 1840's) when political extremes met in individual beliefs more frequently than has often been the case, and he was himself very much the product of such a meeting. The chaos wrought by capitalist industrialism produced in him, as well as many others, a bewildering mixture of the old and the new, the sacred and profane, and the "progressive" and "reactionary", and in this regard Owen's paradoxical make-up and beliefs have a considerable affinity to those of men like Oastler, Bernard and Stephens, whose political principles combined to produce a peculiar brand of Tory radicalism and even revolutionism.

But if Owen more or less consistently combined certain extremes throughout his life, nonetheless it should be evident that his project was also quite different from that of men like Oastler and Stephens. He was a "paternalist", but yet synthesised and developed this principle in an egalitarian framework as foreign to "altar, king, and cottage" (or any other landmark of what is usually termed "paternalism") as it was possible to be. He believed in the principle of hierarchy as a basis of benevolent, kind and watchful government, but his choice of principle belongs more to anthropological theory (or the antipodes of dissent) than it does to any form of doctrinaire conservatism. And, for all this, Owen was also a "democrat", doubtless lying outside of the mainstream tradition of democratic theory through his opposition to representative governments, but nonetheless deeply committed to a conception of equality which, to Owen's mind, materially fulfilled what were otherwise empty rhetorical claims about equal rights and equal treatment by social institutions. Nor can such views be characterised as merely a reduction of radical political claims to their ostensibly "real" social content, for Owen's concern was not only with the standard of living of the working classes, irrespective of the form of government under which they lived. This misinterpretation is based, as we have seen, upon statements which were meant to refer only to the introduction of the co-operative system, not to its eventual mode of operation.

Owen did, I think, believe that all human beings, ideally educated to the same standard, held the same right to govern; indeed the plasticity imputed 
by him to human nature could scarcely lead to any other conclusion. Equally importantly he realised that those who inhabited his communities (however misled they were as to the importance of political form in the interim period) would share democratic concerns and would not cease agitating until all participated in government. He clearly realised, too, that his social system could not work if non-producers governed and producers obeyed. He not only believed too much in the ethos of labour to let this occur, seeing all non-producers as a burden upon producers, and holding it to be just that all should share necessary labour. He also held that any form of government might prove an equal burden, were it not closely linked to the interests of the producers themselves. Owen's "democratic" ideal, then, antedates the compromises of republicanism with commercial society, from which issued forth (through the theory of representative government) the theoretical possibility of large republics, and rather invoked an earlier variety of republicanism predicated upon a basis of small communities. This much latitude his faith in a paternal form of government gave him, and his rationalism, seeking one language, one form of social organisation, the abolition of state boundaries, and the like, demanded of him.

Owen's politics merit reconsideration, then, not only to lay bare this eclecticism, nor in order to fix the judgment of another (new or old) category upon him; the language of political description is in any case too impoverished to make such a task simple. It is of course important to evaluate Owen's ideas and behaviour in such terms, and far more so to emphasise the specific meaning of such key "political" terms as occur in his vocabulary, and to assess the extent to which there was development and alteration in his opinions and practices. But it is equally important to consider not how Owen's politics can be re-interpreted in terms of relatively fixed political categories, or even why he was, within the terms of such categories, "unpolitical", but rather how it was that he avoided conformity with this language in an effort to supersede and abolish "politics", how he reacted to the political, rather than to events and people, in that space in his mind which was, after all, not vacant but rather overflowing with response. It is in this unpolitical space that Owen's political significance can alone be gauged. The replacement of politics by "unity" has been an ambiguous, and most would agree a dangerous, legacy, willed and inherited since Owen far more self-consciously than ever before him. It is a phenomenon, however, which has been far too little explored, and if its manifestation is only deceptively simple in Owen, the chances are good that this is equally true elsewhere. 